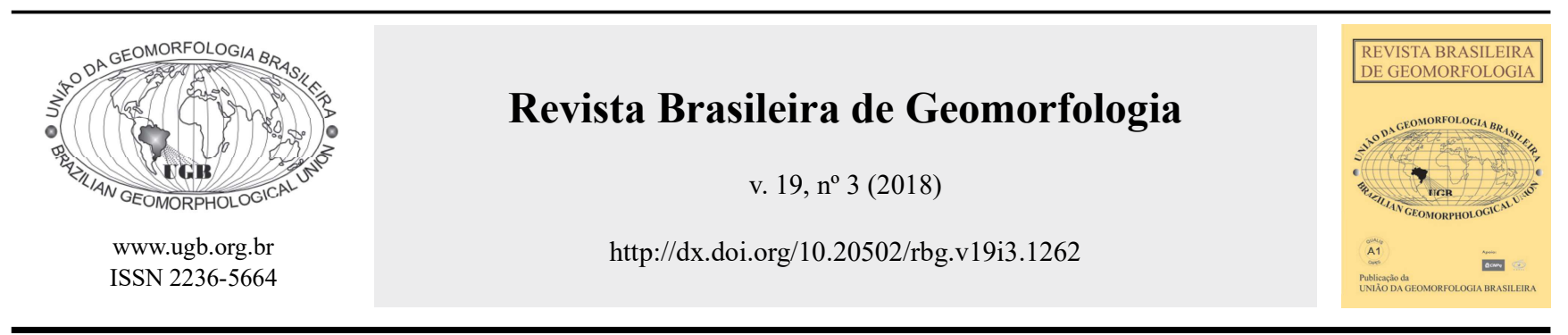

\title{
GEOCHRONOLOGY AND HYDRODYNAMIC ENERGY CONDITIONS IN SURFACE COVERINGS OF LOW HOLOCENE FLUVIAL, FLUVIAL- MARINE, AND MARINE TERRACES: CLIMATIC PULSATIONS TO THE SOUTH OF THE ARANGUAGUÁ RIVER BASIN (SC)
}

\section{GEOCRONOLOGIA E CONDIÇÕES ENERGÉTICAS HIDRODINÂMICAS EM COBERTURAS SUPERFICIAIS DE BAIXOS TERRAÇOS FLUVIAIS, FLUVIOMARINHOS E MARINHOS HOLOCÊNICOS: PULSAÇÕES CLIMÁTICAS AO SUL DA BACIA HIDROGRÁFICA DO RIO ARARANGUÁ (SC)}

Felipe Gomes Rubira

Departamento de Geografia, Universidade Estadual de Campinas Rua João Pandiá Calógeras, 51, Campinas, São Paulo. CEP: 13087-870. Brasil

Email:felipe_rubira@hotmail.com

Archimedes Perez Filho

Departamento de Geografia, Universidade Estadual de Campinas Rua João Pandiá Calógeras, 51, Campinas, São Paulo. CEP: 13087-870. Brasil

Email:archi@ige.unicamp.br

\section{Informações sobre o Artigo}

Data de Recebimento: 25/02/2018

Data de Aprovação: $08 / 05 / 2018$

\section{Keywords:}

Climatic Pulsations; Depositional Events; Energy Intensity.

\section{Palavras-chave:}

Pulsações Climáticas; Eventos Deposicionais; Intensidade Energética.

\begin{abstract}
:
This research aims to perform the geochronology of surface coverings in low Holocene marine, fluvial-marine, and fluvial terraces, associating the genesis of paleo-forms with the occurrence of Holocene climatic pulsations, the consequential switches between hot-dry/hot-wet continental phases, and the retrograde and prograde movements of the oceanic coast due to eustatic sea-level fluctuations. At the same time, it aims to verify and correlate specific hydrodynamic energy conditions during past depositional events, responsible for preparing the levels of low fluvial, fluvial-marine, and marine terraces to the south of the Araranguá river (SC). The methodology was based in absolute dating through Optically Stimulated Luminescence (OSL) in quartz grains of the surface coverings of these low terraces and in granulometric tests with later data plotting and verification of sediment types, textural classes, and the respective paleo-hydrodynamic energy conditions, classified based on the textural diagram of Flemming (2000). Results of geochronological reconstruction corresponded to climatic events of switches between hot-dry/hot-wet environments and to global cooling periods identified by Bond et al. $(1997,2001)$ and Wanner et al. (2011). Three Holocene climatic pulsations were identified, which were determinant for the superficial organization of the landscape in the lower course of the Ararangua river and the oceanic plain of the Araranguá River Basin: Climatic pulsation I (6.000 \pm 820 to $5.000 \pm 620$
\end{abstract}


Years B.P.), climatic pulsation II ( $2.700 \pm 420$ to $2.250 \pm 300$ Years B.P.) and climatic pulsation III ( $420 \pm 65$ to 215 \pm 25 Years B.P.). The application of results in the textural diagram of Flemming (2000) allowed the differentiation of sedimentation environments, which were correlated with varied hydrodynamic energy regimes. Surface coverings of the low fluvial terrace (GS-I) and the alluvial materials of the low fluvial-marine terrace (GS-II) presented the highest mud content among all samples, which was correlated with moderate and moderate-to-high hydrodynamic energy transport flows. On the other hand, surface coverings of marine terraces (GS-III and GS-IV) and the marine sandy materials underlying alluvial deposits of the fluvial-marine terrace showed low levels of mud and high levels of sand, representing high- and very high-intensity hydrodynamic energy flows.

\section{Resumo:}

Esta pesquisa objetiva realizar geocronologia das coberturas superficiais em níveis de baixos terraços fluviais, fluviomarinhos e marinhos holocênicos, associando a gênese das paleoformas com a ocorrência de pulsações climáticas holocênicas, consequentes alternâncias de fases continentais quentes-secas/quentes-úmidas e movimentos de progradação e retrogradação da costa oceânica em função de flutuações eustáticas do nível relativo do mar. Simultaneamente objetiva verificar e correlacionar às condições energéticas hidrodinâmicas durante eventos deposicionais pretéritos, responsáveis por elaborar os níveis de baixos terraços fluviais, fluviomarinhos e marinhos ao sul do rio Araranguá (SC). A metodologia baseou-se em datações absolutas por Luminescência Opticamente Estimulada (LOE) em grãos de Quartzo das coberturas superficiais dos baixos terraços e testes granulométricos com posterior plotação dos dados e verificação dos tipos de sedimentos, classes texturais e respectivas condições energéticas paleohidrodinâmicas, classificadas com base no diagrama textural de Flemming (2000). Os resultados provenientes da reconstituição geocronológica apresentaram correspondência com eventos climáticos de alternâncias entre ambientes quentes-úmidos/quentes-secos e a períodos de resfriamentos globais identificados por Bond et al. (1997, 2001) e Wanner et al. (2011). Foram identificadas três pulsações climáticas holocênicas determinantes para organização superficial da paisagem do baixo curso do rio Araranguá e planície oceânica da bacia hidrográfica do rio Araranguá: Pulsação climática I (6.000 \pm 820 a 5.000 \pm 620 Anos A.P); Pulsação climática II (2.700 \pm 420 a $2.250 \pm 300$ anos A.P.) e Pulsação climática III (420 \pm 65 a $215 \pm 25$ anos A.P.). A aplicação dos resultados no diagrama textural de Flemming (2000), permitiu a distinção de ambientes de sedimentação, caracterizados por regimes energéticos hidrodinâmicos variados. As coberturas superficiais do baixo terraço fluvial (SG-I) e, os materiais aluviais superficiais do baixo terraço fluviomarinho (SG-II), apresentaram os maiores teores de lama entre todas as amostras, sendo correlacionados a fluxos energéticos hidrodinâmicos de transporte moderados e moderados altos. As coberturas superficiais dos baixos terraços marinhos (SG-III e SG-IV) e dos materiais arenosos marinhos, subjacentes aos depósitos aluviais do baixo terraço fluviomarinho, apresentaram baixos teores de lama e elevada porcentagem de fração areia, sendo associados a fluxos energéticos hidrodinâmicos de intensidade alta e muito alta.

\section{Introduction}

The study of the relationship between forms of fluvial, marine, and fluvial-marine terraces and their surface coverings, in conjunction with the hydrodynamic energy conditions during prior depositional events and associated with the hypothesis of Holocene climatic pulsations, offer essential subsidies to the success of geochronological reconstructions and preparation of evolutionary theoretical models of hydro-pedomorphological systems in fluvial and marine environments.

Starting from the theoretical assumption that terraces represent ancient flood plains (fluvial terraces) and submerged areas, previously belonging to the continental shelf (marine and fluvial-marine terraces), it becomes essential to investigate the geochronology of depositional events (genesis) and the intensity of fluvial and marine hydrodynamic flows that are responsible for transporting, selecting, and depositing the surface coverings overlapping the plane surfaces of the studied geomorphological compartments, in an attempt to establish paleo-evolutionary correlations regarding prior energy states and the superficial organization of the landscape.

To Flemming (2000), sandy sediments reflect depositions under higher energy conditions and are 
increasingly segregated from muddy sediments (silt and clay), which reflect depositional events under lower energy conditions. According to this author, such premise allows the hydrodynamic classification and the association of the sedimentary deposit with the energy of the transport agent. To this end, he developed, from modifications of the Reineck and Siefert (1980) and Pejrup (1988) models, a new triangular diagram for textural classification of deposits, along with the respective hydrodynamic energy of transport conditions.

Originally, the ternary textural diagram of Flemming (2000) was developed to classify muddy sediments deposited in macro-tide estuarine environments of the external platform through hydrodynamic criteria. However, currently, it is possible to observe its successful adaptation for studies that have applied this methodology in geomorphological systems other than those originally proposed, such as the studies led by Oliveira and Lima (2004) and Oliveira et al. (2006) on quaternary sediments from valley headwaters in the municipality of Campo Alegre (SC); Castilho (2008) on lagoon environments, studying the case of Quiaios lagoons in Portugal; Lima (2010) on alluvial and alluvium-colluvial deposits in five sedimentary sequences, studied at the Plateau of São Bento do Sul and at the Parque Estadual da Serra do Tabuleiro in Santa Catarina; Alves (2013) on lowercourse geomorphological compartments of the Negro River (AM). Results of these studies provided subsidies for the paleo-hydrological interpretations in continental environments.

Therefore, will the methodology, when applied to surface coverings of low marine, fluvial-marine, and fluvial terraces, have the same consistency observed in applications into fluvial, lagoon, colluvial, and estuarine systems? Will it present associations between hydrodynamic energy conditions by the granulometric fraction and textural class variations of sand, silt, and clay particles?

Thus, the research problem was structured, aiming to perform the geochronology of surface coverings in low Holocene marine, fluvial-marine, and fluvial terraces, associating the genesis of paleo-forms with the occurrence of Holocene climatic pulsations, the consequential switches between hot-dry/hot-wet continental phases, and the retrograde and prograde movements of the oceanic coast due to eustatic sealevel fluctuations. At the same time, it aims to verify and correlate specific hydrodynamic energy conditions during past depositional events, responsible for preparing the levels of low fluvial, fluvial-marine, and marine terraces to the south of the Araranguá River Basin (SC).

To this end, Optically Stimulated Luminescence dating (OSL) and granulometric analyses were performed on the surface coverings of the low terraces. Hence, it was possible to verify the moment of the last exposure of the materials to sunlight and to define the ages of depositional events responsible for originating the geomorphic surfaces studied.

Results of sand, silt, and clay fractions plotted in the ternary textural diagram of Flemming (2000), as well as the revelation of ages of depositional events (OSL), provided subsidies for the association of surface covering with the transport agent (marine and fluvial) energy and assisted the geochronological reconstructions and paleo-hydrologic interpretations of fluvial-marine environments.

It is necessary to emphasize that the decrease or increase in the intensity potential of specific hydrodynamic energy conditions are not independent, being one of the paleoclimatic variables related to glacial and interglacial stages, drier and wetter continental phases, and transgression and regression movements of the relative sea level.

\section{Methodology}

\subsection{Cartographic products and identification of fluvial, fluvial-marine, and marine terraces}

The Araranguá River basin (SC) delimitation, Digital Elevation Model (DEM) development, topographic profiles construction, and location of sampling points were all performed by the ArcGIS software 10.5.1 and Global Mapper 18.0. Radar images with 30-meter spatial resolution were used as the cartographic base. These cartographic procedures enabled the preliminary identification of low marine, fluvial, and fluvial-marine terraces, which later were confirmed by field work.

Trenches were opened in the levels of the terraces. Later, samples of the covering materials of the marine geomorphological surfaces were collected and identified for physical analyses and OSL absolute dating in the laboratory. Collection depths were set based on the outcrop of subsurface flow. 


\subsection{Optically Stimulated Luminescence dating}

Sallun et al. (2007) dictate that ages obtained by crystal luminescence in quaternary-period sediments are worldwide accepted in the scientific world today and constitute an important tool in research proposing the reconstruction of chronological events.

The method developed by Huntley et al. (1985) enabled measuring the luminescence signal directly related to the load of an electron population trapped in crystalline solids (minerals), found in the very deposits through light stimulus. These minerals are quartz and feldspar (HUNTLEY et al., 1991).

Through the technique developed by Huntley et al. (1985), geochronological studies that managed to show the last exposure of the sediments to sunlight were started, correlating them to depositional events occurring in the Pleistocene and Holocene.

According to Huntley et al. (1985, 1991, 1996), the emission of energy from sunlight releases electrons trapped in crystalline solids and reduces the OSL signal to zero (age). After a new depositional process, these grains that were exposed on the surface start to accumulate a new OSL signal.

Age (I) is obtained by measuring the dose stored in the grains analyzed $(\mathrm{P})$, divided by the ionizing radiation rate. Sallun et al. (2007) presents the equation:

$$
I=\frac{\mathrm{P}}{\mathrm{DA} \gamma+D A \beta+D A r \cdot C}
$$

where:

I = Age;

$\mathrm{P}=$ Paleodose $(\mathrm{G} \gamma)$, which corresponds to the total energy absorbed by the crystal through the incidence of ionizing radiations;

$\mathrm{DA} \gamma+\mathrm{DA} \beta+\mathrm{DAr} . \mathrm{c}=$ annual doses $(\mathrm{G} \gamma /$ year $)$ related to gamma, beta, and cosmic radiation doses, respectively.

The annual doses and radiation rates of sediments were obtained from determination of the levels of $\mathrm{U}^{235}$ / $\mathrm{U}^{238}$ (Uranium), $\mathrm{Th}^{232}$ (ppm) (Thorium), and $\mathrm{K}^{40}(\%)$ (Potassium), by $\gamma$-ray spectroscopy of the natural sample without any treatment.

Thus, it is established the period of time since the trapped electron population was released for the last time (time of deposition) and the age of the sample is determined, showing when it was last exposed to sunlight, hence estimating the period of deposition (MURRAY e WINTLE, 1998).

Absolute dating by Optically Stimulated Luminescence (OSL) were performed by the DATAÇÃO Laboratory (Dating, Commerce \& Services Provision LTDA - São Paulo/SP), using the SAR (Single Aliquot Regenerative-dose) in quartz grains as proposed by Wintle and Murray (2000) and Murray and Wintle (2000), with 15 aliquots (calibration curves), to determine the time of deposition of the surface coverings in fluvial, fluvial-marine, and marine terraces.

The sample collections of surface materials from the terraces for OSL absolute dating were carried out through the opening of trenches. For this purpose, Polyvinyl Chloride (PVC) tubes with dark colors were used, of approximately 60 centimeters of length and six centimeters of diameter, so the samples were not exposed to solar radiation. These tubes were placed horizontally in vertical profiles of the surface covering.

\subsection{Granulometric analyses}

Granulometric analyses were conducted on samples collected in surface coverings of the low fluvial, fluvialmarine, and marine terraces, aiming at the identification and quantification of the fractions of sand through sieving (very coarse, coarse, medium, fine, very fine) and of silt/ clay by pipetting. These procedures were based on the methodology developed by Camargo et al. (2009).

For the textural classification surface coverings, the granulometric scale of the United States Department of Agriculture - USDA published in 1993 (Table 1) was used.

Table 1: USDA granulometric scale (1993)

\begin{tabular}{c|c}
\hline Fraction & Diameter $(\mathbf{m m})$ \\
\hline Clay & $<0.002$ \\
\hline Silt & $0.05-0.002$ \\
\hline Very fine sand & $0.1-0.05$ \\
\hline Fine sand & $0.25-0.1$ \\
\hline Medium sand & $0.5-0.25$ \\
\hline Coarse sand & $1.0-0.5$ \\
\hline Very coarse sand & $2.0-1.0$ \\
\hline Gravel & $>2$
\end{tabular}




\subsection{Textural classification and correlation with the} hydrodynamic energy conditions

Textural classifications and correlations with hydrodynamic energy conditions were based on the triangular textural diagram of Flemming (2000). Such scheme was drawn up from the modification and expansion of classifications proposed by the textural diagrams of Reineck and Siefert (1980) and Pejrup (1988) (Figure 1).

Based on the models of Reineck and Siefert (1980)

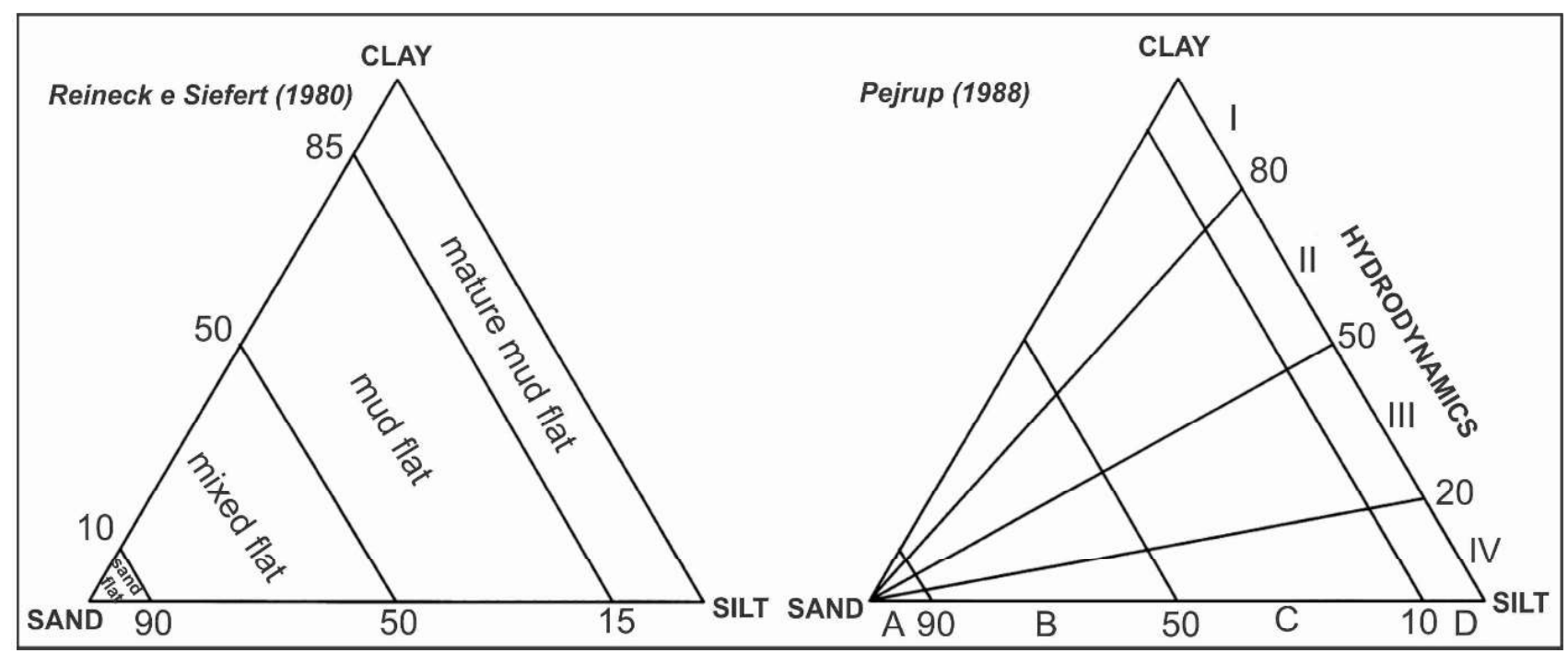

Figure 1 - Ternary diagrams drawn by Reinecke and Siefert (1980) and Pejrup (1988) for textural classification of sediments based on sand/ mud relations. Adapted from Flemming (2000).

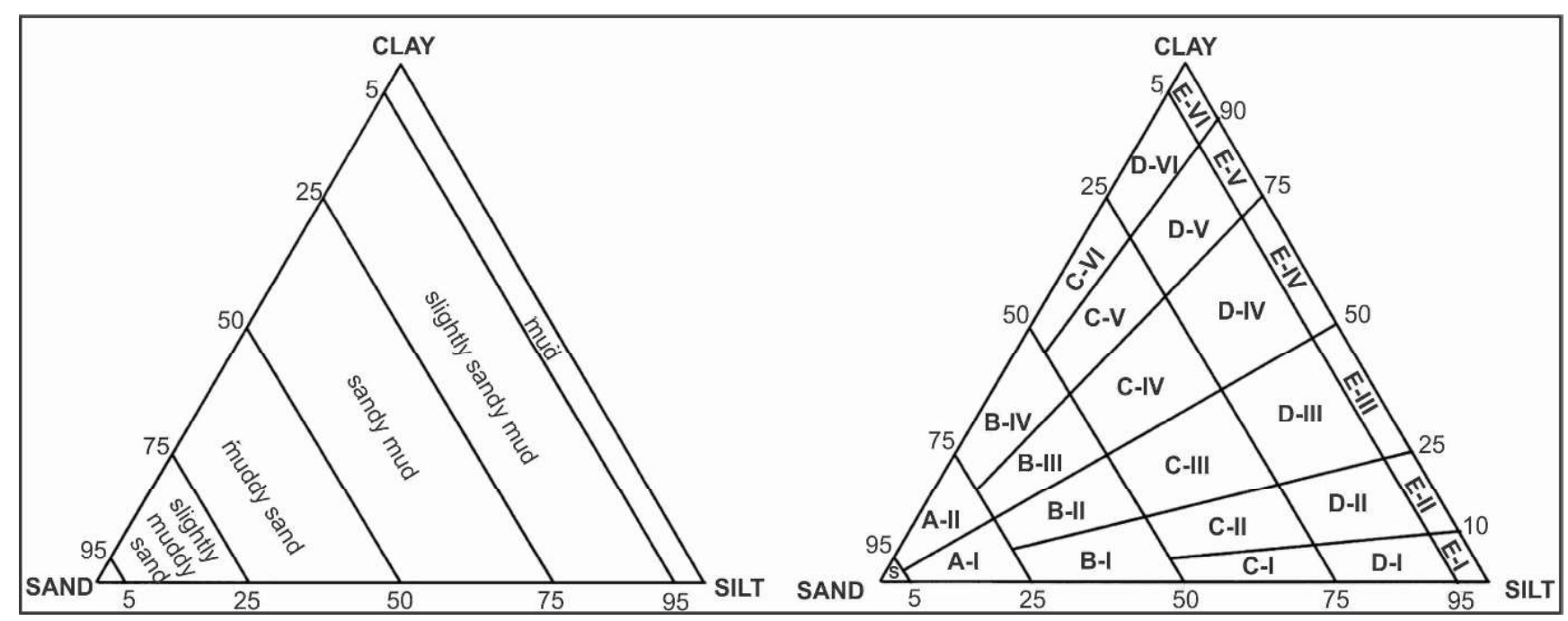

Figure 2 - Ternary diagrams for textural classification and subdivisions regarding hydrodynamic energy capacity for depositional events based on sand/silt/clay relations. The simple scheme distinguishes six textural classes based on correlations between sand and mud. The more complex model includes 25 textural classes associated with the proportions of sand/silt/clay and the energy intensity. Adapted from Flemming (2000). 
For Flemming (2000), this model, when compared to those of Reineck and Siefert (1980) and Pejrup (1988), allows for greater textural range between sand/ mud relations, while at the same time forms the basis for a more complex classification between three sediment components (sand/silt/clay).

The more complex scheme includes the lateral subdivision of components and allows for greater differentiation between sand/silt/clay fractions, amounting to ten partition lines. In this way, the class of Sand remains undivided; the category of Slightly muddy sand is divided into two subclasses, aimed at the distinction of sands with higher levels of silt or clay content; the category of Muddy sand is divided into four subclasses, showing areas of silt and clay; the categories of Sandy mud, Mud, and Slightly sandy mud are divided into six subclasses, also according to the proportions of silt and clay.

Thus, Flemming (2000) created 25 textural classes associated with sand/silt/clay proportions, specified by codes represented by letters and Roman numerals (Table 2).

Table 2: Numeric codes and descriptive terminology for the 25 textural classes based on sand/silt/clay relations defined by Flemming (2000), representing different hydrodynamic regimes for depositional events. The code " $S$ " represents a very high hydrodynamic intensity; "A" stands for high; "B" moderate to high; "C" moderate; "D" low; " $E$ " for very low. Adapted from Flemming (2000).

\begin{tabular}{|c|c|c|c|}
\hline Code & $\begin{array}{c}\text { Type of } \\
\text { Sediment }\end{array}$ & Mud content (\%) & Textural class \\
\hline $\mathrm{S}$ & Sand & $<5 \%$ & Sand \\
\hline $\begin{array}{l}\text { A-I } \\
\text { A-II }\end{array}$ & $\begin{array}{c}\text { Slightly muddy } \\
\text { sand }\end{array}$ & $5-25 \%$ & $\begin{array}{l}\text { Slightly silty sand } \\
\text { Slightly clayey sand }\end{array}$ \\
\hline $\begin{array}{l}\text { B-I } \\
\text { B-II } \\
\text { B-III } \\
\text { B-IV } \\
\end{array}$ & Muddy sand & $25-50 \%$ & $\begin{array}{l}\text { Very silty sand } \\
\text { Silty sand } \\
\text { Clayey sand } \\
\text { Very clayey sand }\end{array}$ \\
\hline $\begin{array}{l}\text { C-I } \\
\text { C-II } \\
\text { C-III } \\
\text { C-IV } \\
\text { C-V } \\
\text { C-VI } \\
\end{array}$ & Sandy mud & $50-75 \%$ & $\begin{array}{l}\text { Extremely silty sandy mud } \\
\text { Very silty sandy mud } \\
\text { Silty sandy mud } \\
\text { Clayey sandy mud } \\
\text { Very clayey sandy mud } \\
\text { Extremely clayey sandy mud } \\
\end{array}$ \\
\hline $\begin{array}{l}\text { D-I } \\
\text { D-II } \\
\text { D-III } \\
\text { D-IV } \\
\text { D-V } \\
\text { D-VI }\end{array}$ & $\begin{array}{l}\text { Slightly sandy } \\
\text { mud }\end{array}$ & $75-95 \%$ & $\begin{array}{l}\text { Extremely silty slightly sandy mud } \\
\text { Very silty slightly sandy mud } \\
\text { Silty slightly sandy mud } \\
\text { Clayey slightly sandy mud } \\
\text { Very clayey slightly sandy mud } \\
\text { Extremely clayey slightly sandy mud }\end{array}$ \\
\hline $\begin{array}{l}\text { E-I } \\
\text { E-II } \\
\text { E-III } \\
\text { E-IV } \\
\text { E-V } \\
\text { E-VI }\end{array}$ & Mud & $>95 \%$ & $\begin{array}{l}\text { Silt } \\
\text { Slightly clayey silt } \\
\text { Clayey silt } \\
\text { Silty clay } \\
\text { Slightly silty clay } \\
\text { Clay }\end{array}$ \\
\hline
\end{tabular}




\section{Geochronology and Hydrodynamic Energy Conditions in Surface Coverings of Low Holocene Fluvial}

From this methodological approach, Flemming (2000) incorporates correlations between textural classes and different hydrodynamic regimes, reflected by the spatialization of the samples in the diagram, which indicates the specific transport energy conditions of a given material.

Considering the reflections of Bagnold (1968) and Pejrup (1988) that the grains are submitted to a size screening during the hydraulic transport, which would result in a selective deposition along a gradient of energy; Flemming (2000) identifies that, the closer the set of samples are in relation to the final member of the triangle (sand), the higher will the energy level be. In contrast, the closer it is to the vertex of clay, the lower the energy intensity will be.

The granulometric results were plotted in the ternary textural diagram of Flemming (2000) and, thus, the correlation of textural classes with hydrodynamic energy conditions of transport of surface coverings was performed in different depositional moments.

\section{Location and Geomorphological Subdivision of the Area}

The study area is located on the South coast of the State of Santa Catarina and corresponds to the Araranguá River Basin (Figure 3).

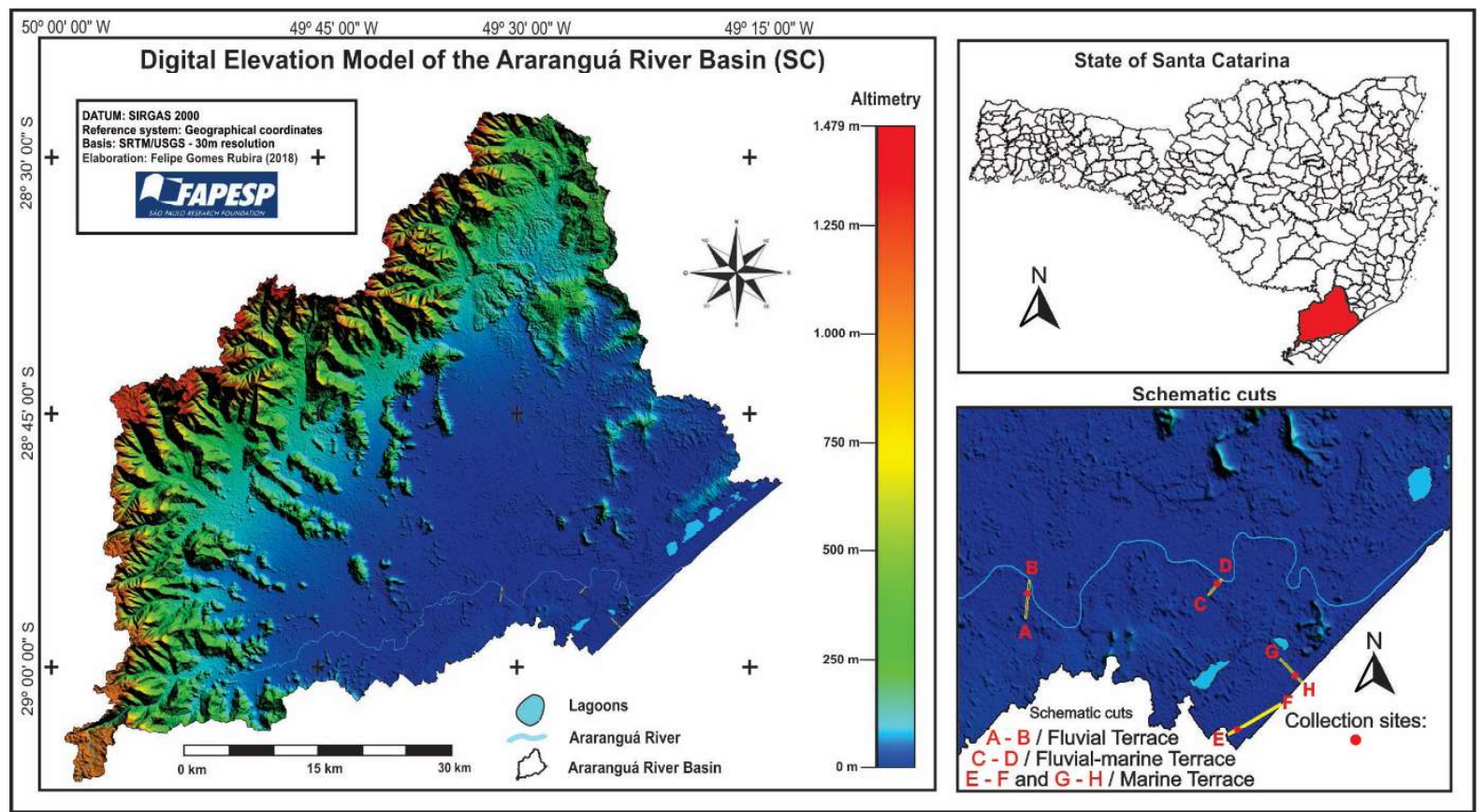

Figure 3 - Location of the study area, digital elevation model of the Araranguá River basin, and schematic cuts of the four geomorphological surfaces analyzed.

The Araranguá River traverses, along its path, four geological/geomorphological compartments, laid out in the river basin. From East to West: Coastal Plain, Mountains of eastern Santa Catarina, and the Serra Geral foothills and slopes. The succession of these compartments is characterized by steep slopes, with more than 1000 meters in altimetric breadth between the Araranguá River spring and mouth.

The low terraces identified and selected, inserted in the context of the low course and mouth of the Araranguá River, corresponding to the four areas assessed, are located in the Coastal Plain geomorphological compartment, formed by the overlapping of marine (Q1m1, Q1m2, Q1fm, Q2m2, Q2m1), eolian (Q2e), fluvial (Q1f, Q1 fm), and lagoon (Q11) deposits (Figure 4).

\section{Results}

Optically Stimulated Luminescence dating was performed in all Holocene geomorphologic surfaces located to the south of the Araranguá River (Table 3 ). These results helped and provided subsidies for geochronological reconstructions of Holocene depositional events. 


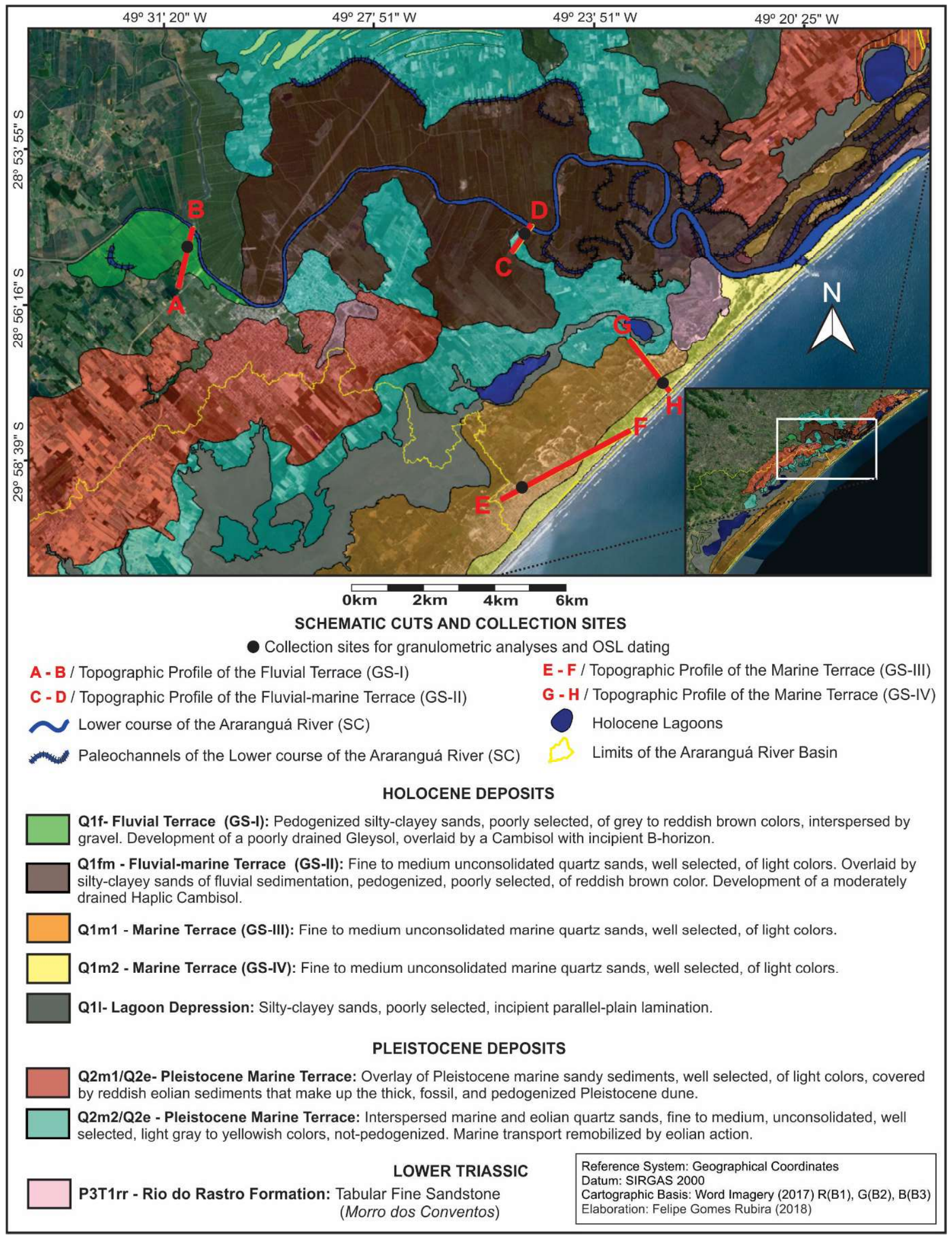

Figure 4 - Description and spatialization of the surface coverings of four Holocene geomorphological surfaces (GS) identified to the South of the Araranguá River Basin, corresponding to low marine (GS-III and GS-IV), fluvial-marine (GS-II), and fluvial (GS-I) terraces. Schematic cuts " $A-B / C-D / E-F / G-H$ ” of the topographic profiles devised. 
Table 3: Description of the samples (depth, location, and altitude of the terraces) and results of the ages obtained by OSL absolute dating in surface coverings, related to Holocene depositional events linked to the genesis of the low terraces of the southern Araranguá River basin

\begin{tabular}{|c|c|c|c|c|c|}
\hline \multicolumn{6}{|c|}{ Samples description and Results of Ages } \\
\hline $\begin{array}{c}\text { Relief } \\
\text { Unit }\end{array}$ & $\begin{array}{c}\text { Geographical } \\
\text { Coordinates } \\
(x, y)\end{array}$ & $\begin{array}{c}\text { Terrace } \\
\text { altitude (m) }\end{array}$ & $\begin{array}{c}\text { Depth of } \\
\text { collection }(\mathbf{c m})\end{array}$ & Texture & Age (Years) \\
\hline $\begin{array}{l}\text { Low Fluvial } \\
\text { Terrace } \\
\text { (GS - I) }\end{array}$ & $\begin{array}{l}28^{\circ} 55^{\prime} 22.19^{\prime \prime} \mathrm{S} \\
49^{\circ} 30^{\prime} 52.55^{\prime \prime} \mathrm{W}\end{array}$ & 2.5 & 60 & Silty sand & $2.250 \pm 300$ \\
\hline $\begin{array}{l}\text { Low Fluvial- } \\
\text { Marine Terrace } \\
\text { (GS - II) }\end{array}$ & $\begin{array}{l}28^{\circ} 55^{\prime} 04.11^{\prime} \mathrm{S} \\
49^{\circ} 25^{\prime} 09.00^{\prime \prime} \mathrm{W}\end{array}$ & 3 & 110 & $\begin{array}{l}\text { Clayey sandy mud } \\
\text { Slightly clayey sand }\end{array}$ & $\begin{array}{l}2.700 \pm 420 \\
5.000 \pm 620\end{array}$ \\
\hline & & & 170 & Sand & $6.000 \pm 820$ \\
\hline $\begin{array}{l}\text { Low Marine } \\
\text { Terrace } \\
\text { (GS - III) }\end{array}$ & $\begin{array}{l}49^{\circ} 25^{\prime} 06.59^{\prime \prime} \mathrm{W} \\
28^{\circ} 58^{\prime} 55.58^{\prime \prime} \mathrm{S}\end{array}$ & 7.5 & $\begin{array}{l}40 \\
65\end{array}$ & $\begin{array}{c}\text { Sand } \\
\text { Slightly silty sand }\end{array}$ & $\begin{array}{l}210 \pm 25 \\
215 \pm 25\end{array}$ \\
\hline $\begin{array}{l}\text { Low Marine } \\
\text { Terrace } \\
(\mathrm{GS}-\mathrm{IV})\end{array}$ & $\begin{array}{l}49^{\circ} 22^{\prime} 46.84^{\prime \prime} \mathrm{W} \\
28^{\circ} 57^{\prime} 17.27^{\prime \prime} \mathrm{S}\end{array}$ & 4.5 & $\begin{array}{l}50 \\
75\end{array}$ & $\begin{array}{l}\text { Sand } \\
\text { Sand }\end{array}$ & $165 \pm 35$ \\
\hline
\end{tabular}

\subsection{Low fluvial terrace, surface coverings, and OSL dating}

The geomorphological surface I(GS-1) corresponds to the low fluvial terrace with genesis tied to the Holocene climatic pulsation $(2.700 \pm 420$ to $2.250 \pm 300$ years B.P.).

It has a flat and smoothed surface toward the watercourse and terminates near the contact with the marginal dike of the Araranguá River, and the top reaches 4 meter and the base 2.5 meters above the current relative sea level (Figure 5). In this stretch, the Araranguá River is located at 3 meters high (during the full periods). Due to grading processes of the alluvium bed at this location, it is 0.5 meters in elevation regarding the terrace base $(2.5 \mathrm{~m})$. These processes are raised by the reworking of ancient deposits of alluvial fans from the Pliopleistocene, from the retreat of the Serra Geral plateau slope to the West and of the tidal reflux of the Atlantic Ocean, observed in the field, to the East.

The alluvial covering materials of this geomorphologic level underwent pedogenetic processes, responsible for developing Haplic Cambisol with incipient $\mathrm{B}$ horizon moderately drained over Haplic Gleysol (little wet), very badly drained due to the proximity to the water table.

These surface coverings are interconnected by alluvial gravel, composed of pebbles and sub-rolled blocks from residual sandstone elevations of Rio do Rastro formation and basalt highs of the Serra Geral. Such gravel is associated with the paleochannel identified on this terrace, as displayed in Figure 4. Both represent the ancient bed of the Araranguá River.

The climatic pulsation under scrutiny $(2.700 \pm 420$ to $2.250 \pm 300$ years B.P.), related to the production of this fluvial terrace, is associated with the dry continental phase, less wet than the current, corresponding to the fourth global cooling of the Holocene period (2.6002.800 years B.P.) identified by Wanner et al. (2011). These inferences were made on the basis of orbital change data for specific areas in the northern and southern Hemispheres during the summer (Milankovitch, 1920; Werner and Wolff, 2007; Shevenell et al. 2007); sulfate release due to volcanic activity during the last 6.000 years (Gao et al., 2008; Wanner et al., 2008); variations in solar activity through geochronological data from ${ }^{10} \mathrm{Be}$ dating in ice caps (Berger, 1978; Chapman and Shackleton, 2000; Viau et al., 2002; Gupta et al., 2003; Hong et al., 2003; Krivova and Solanki, 2008; Steinhilber et al., 2009; Gray et al., 2010); increased CO2 concentration (Enting, 1987; Stott et al. 2007) and changes in the thermohaline circulation (Bianchi and McCave, 1999; Jennings et al., 2002; IPCC, 2007). 


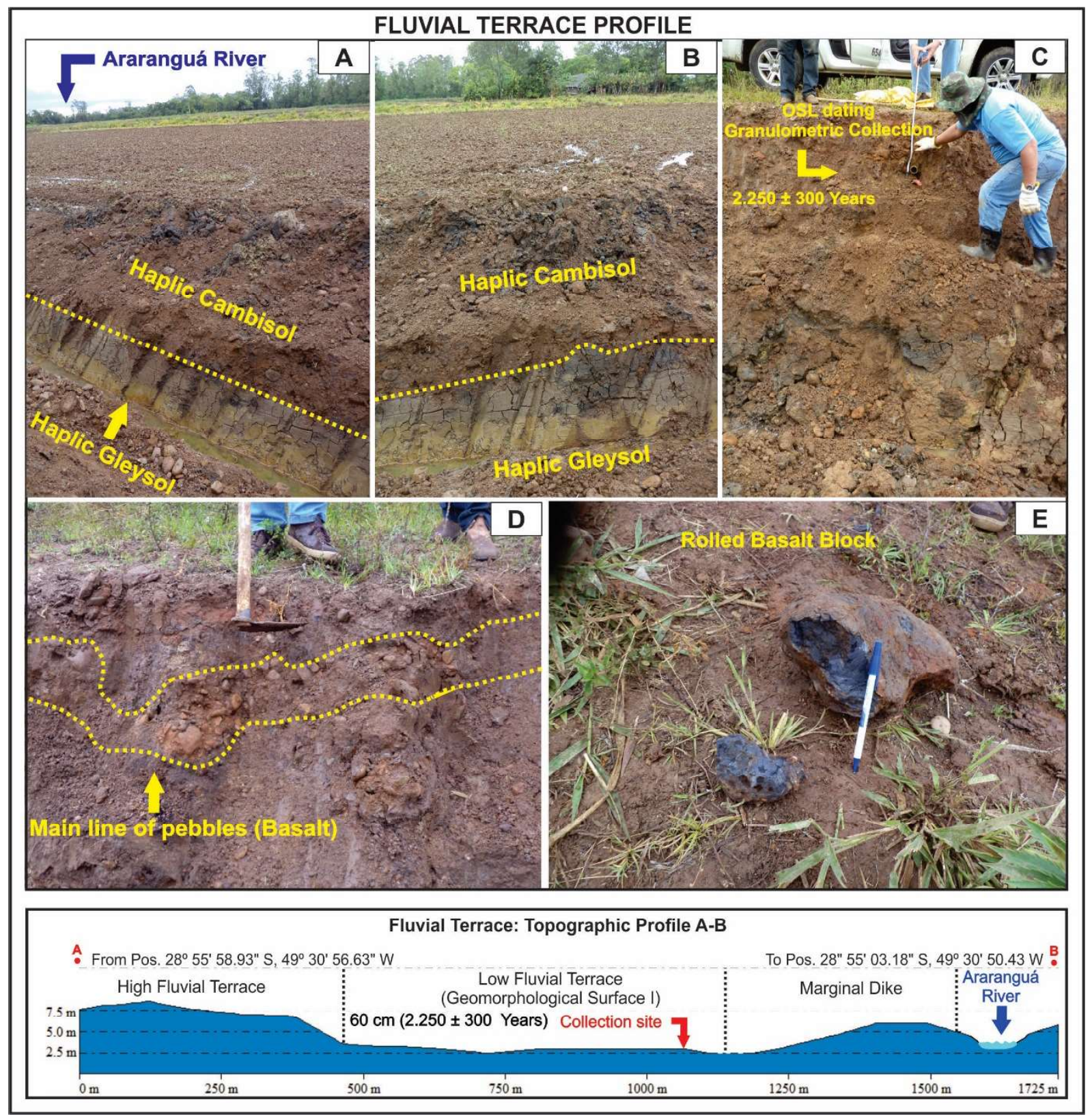

Figure 5 - Topographic profile "A-B" of the fluvial terrace and place of collection. A and B) general appearance of fluvial terrace, pedogenized alluvial sediments (Horizons Overlay - Haplic Gleysol/Haplic Cambisol); C) Collection sites for granulometry and OSL dating; D) Alluvial gravel; E) Basalt pebbles

Such results also corroborate with the driest periods defined by research conducted in Brazil: Behling (1995), drier climate from 2.780 to 970 B.P. in the State of Minas Gerais (pollen analysis in the Pires Lake); Thomas and Thorp (1995), drier climate accompanied by deforestation between 3.100-2.400 years B.P. (C14); Pessenda (1996), with a very dry climatic phase from 2.700 to 2.000 years B.P. in Salitre de Minas, Central Brazil, results determined by carbon isotopes $\left(\mathrm{C}^{13}\right.$ and $\mathrm{C}^{14}$ ) in soil profiles; Stevaux (2000), with an episode of drought from 3.500 to 1.500 years B.P. in the upper course of the Paraná River, determined by pollen analysis, thermoluminescence, and $\mathrm{C}^{14}$ in fluvial terrace levels from 1 to 4 meters deep $(4.780 \pm 100 ; 3.160 \pm 80 ; 3.150 \pm 90$; $2.450 \pm 350 ; 2.050 \pm 80 ; 870 \pm 30 ; 270 \pm 60)$; Behling (2002), resumption of humidity conditions (1.500-1.000) after a dry period, observed in forests of the Serra de Campos Gerais in the State of Paraná; Dias and Perez Filho (2015a), with a transition to a drier period about 2.570 years ago, determined by OSL dating in surface 
coverings of low fluvial terraces in the upper course of the Corumbataí river, in the Peripheral Depression in the State of São Paulo; Storani (2015), through OSL dating in different levels of low fluvial terraces of thirteen rivers in the State of São Paulo, located in the geomorphological compartments of the Peripheral Depression and the Western Plateau of São Paulo.

From such results, it was found that this climatic pulsation is related to a period of stabilization of the relative sea level during an eustatic regression occurred after the maximum Santos transgression (5.000 years B.P.), corresponding to the MIS1e marine isotopic stage (Shackleton, 1969; Lambeck et al. 2002; Railsback et al. 2015a; Railsback et al. 2015b).

This climatic event, resulting from global cooling, was determinant for the installation of a drier continental climate and the production of a low fluvial terrace through the formation of staggered levels and slopes toward the river channel, by the lateral development of plains and deposition of profile materials $(2.250 \pm$ 300 years). Currently, the gradate filling of the river channel bed by fluvial sedimentation is observed, in a new period of sea level stabilization.

\subsection{Low fluvial-marine terrace, surface coverings, and OSL dating}

The geomorphological surface II (GS-II) corresponds to a low fluvial-marine terrace. Sandy marine sediments, deep in the profile, have their genesis correlated to a regressive eustatic movement promoted by Holocene climatic pulsations $\mathbf{( 5 . 0 0 0} \pm \mathbf{6 2 0}$ and $6.000 \pm 820$ years B.P.). These marine depositional layers are overlapped by alluvial materials, also associated with Holocene climatic pulsations (2.700 \pm 420 and $2.250 \pm 300$ years B.P.), responsible for enforcing the alternation of dry and wet continental phases, which were determinant for the selection and deposition of materials transported by the river and for the morphogenetic sculpting of terrace surface during the period of relative sea-level stabilization.

It has a plain surface and smoothed levels towards the Araranguá River and the Atlantic Ocean and terminates near the contact of the marginal dike of the river with the current shoreline. The top is at an altitude of 3 meters and the base, adjacent to the river, is 2.5 meters high. In this transect, the Araranguá River is also at 2.5 meters of altitude. The base of the low fluvial-marine terrace, adjoining the current shoreline, is 1 meter above the relative sea level (Figure 6).

Alluvial materials covering this geomorphological surface featured pedogenetic processes, developing a moderately drained Haplic Cambisol. They were characterized as silty-clayey sands of fluvial sedimentation, pedogenized, poorly selected, of reddish brown color (Figure 6).

Underlying marine materials have signs of leaching in the intermediate stratigraphic layers, with a slight accumulation of clay and evidence of weathered shells. Sediments of these marine deposits were classified as fine to medium unconsolidated quartz sands, well selected, of clear colors (Figure 6).

The depositional event of these marine materials is associated with the regressive eustatic episode that came after the maximum Transgression of Santos, which began 17.500 years B.P. and ended around 5.500 years B.P., corresponding to the MS1 marine isotopic stage (Shackleton, 1969; Lambeck et al. 2002; Railsback et al. 2015a; Railsback et al. 2015b).

Van Andel and Laborel (1964), Komar (1976), Suguio and Martin (1978), Suguio et al. (1985), Angulo and Suguio (1995), Martin et al. (1996), Angulo and Lane (1997), and Suguio (2003) presented data on sea level fluctuations along various stretches of the Brazilian coast and proposed curves for changes of the relative sea level for the various phases of marine transgressions and regressions in the last 7.000 years B.P.

Based on records provided by the authors cited in the previous paragraph, it is considered that Holocene marine terraces of the Brazilian coast were produced from 7.000 years B.P., as the current average level of the sea, according to Suguio et al. (1985), was exceeded for the first time only between 7.000 and 6.500 years B.P., since the occurrence of the maximum marine regression of the last glacial maximum (LGM), when the retreat of $130 \mathrm{~m}$ below the current sea level occurred, which corresponds in the international literature to the MIS2 marine isotopic stage (Shackleton, 1969; Lambeck et al. 2002; Railsback et al. 2015a; Railsback et al. 2015b).

The results of this research meet these assertions and propositions. A depositional event was found between $6.000 \pm 820$ and $5.000 \pm 620$ years B.P., responsible for depositing marine materials during the Holocene eustatic regression started after the peak of Holocene transgression. 


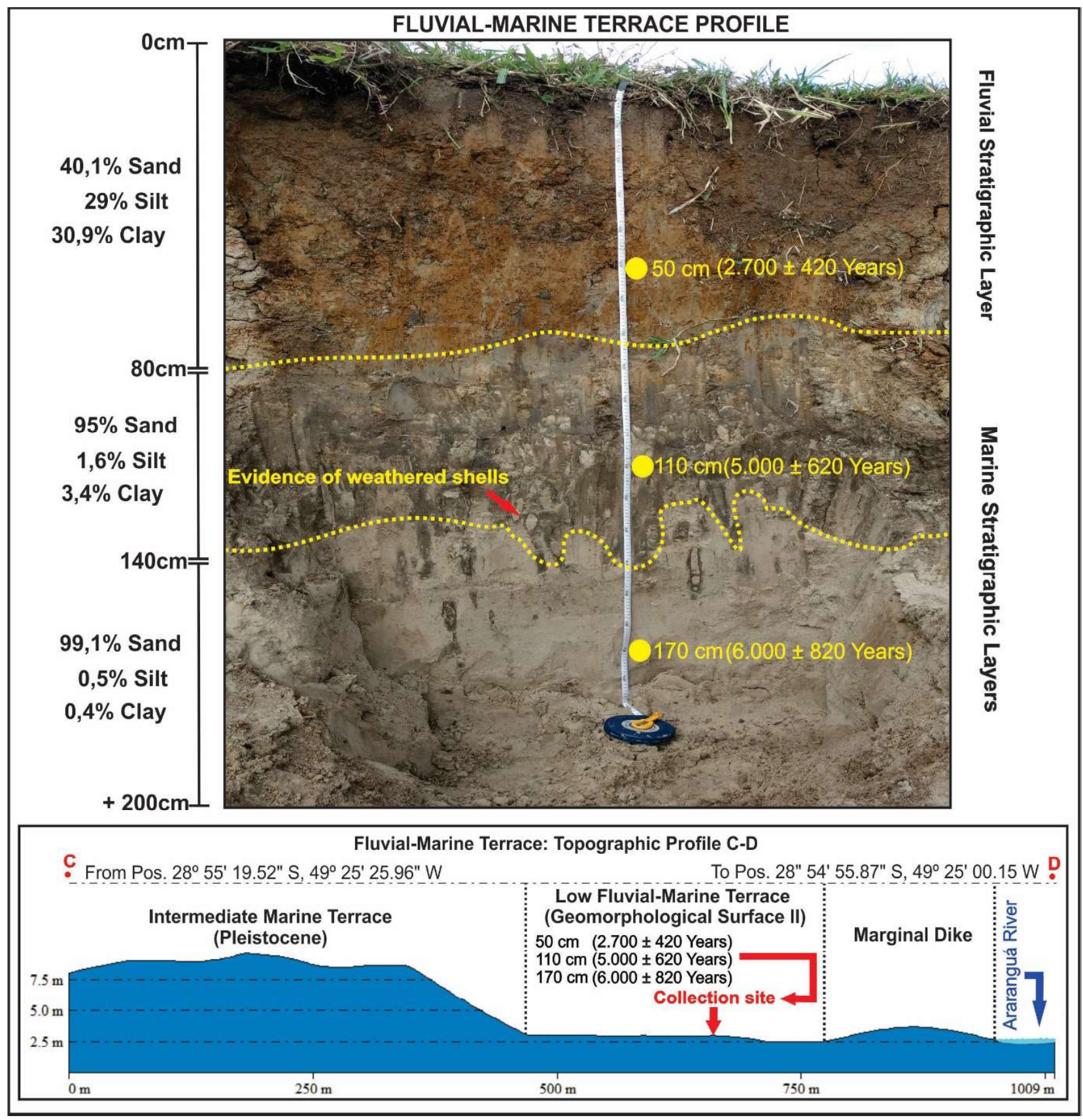

Figure 6- Topographic profile “ $C$-D” of the fluvial-marine terrace and collection site. Profile of stratigraphic layers, granulometric results, and ages of the deposits in the low fluvial-marine terrace. Superficial stratigraphic layer, corresponding to alluvial materials with higher percentages of mud, presenting pedogenetic processes (Haplic Cambisol). Underlying stratigraphic layers correspond to marine depositional events and have a high percentage of sand and unconsolidated sediments.

Regarding the depositional event of alluvial materials $(2.700 \pm 420$ years B.P.), its genesis is attributed to the same Holocene climatic pulsation determinant for the formation of the previously described low fluvial terrace $(2.700 \pm 420$ to $2.250 \pm$ 300 years B.P.), corroborating with the results disclosed by Behling (1995), Thomas and Thorp (1995), Pessenda
(1996), Stevaux (2000), and Dias and Perez Filho (2015a). The deposition of these sediments is closely related to the change of the overall base-level during the marine regression and advancement of the Araranguá River toward the coast, over areas previously submerged by the Atlantic Ocean and previously-deposited marine sediments. 
4.3 Low marine terraces, surface coverings, and OSL dating

The geomorphological surface III (GS-III) also has its genesis linked to eustatic movements raised by Holocene climatic pulsations $(\mathbf{6 . 0 0 0} \pm \mathbf{8 2 0}$ to $210 \pm \mathbf{2 5}$ / $210 \pm 25$ years B.P.). This geomorphological surface is located at the ends of Pleistocene terraces, being separated by elongate depressions parallel to the shoreline, and slope towards the ocean. The top of this surface is 10 meters high and the base is at 5/4 meters (Figure 7).

Marine materials that make up this geomorphological surface do not feature pedogenetic processes and were classified as unconsolidated marine quartz sands, fine to medium, well selected, of light colors (Figure 7).

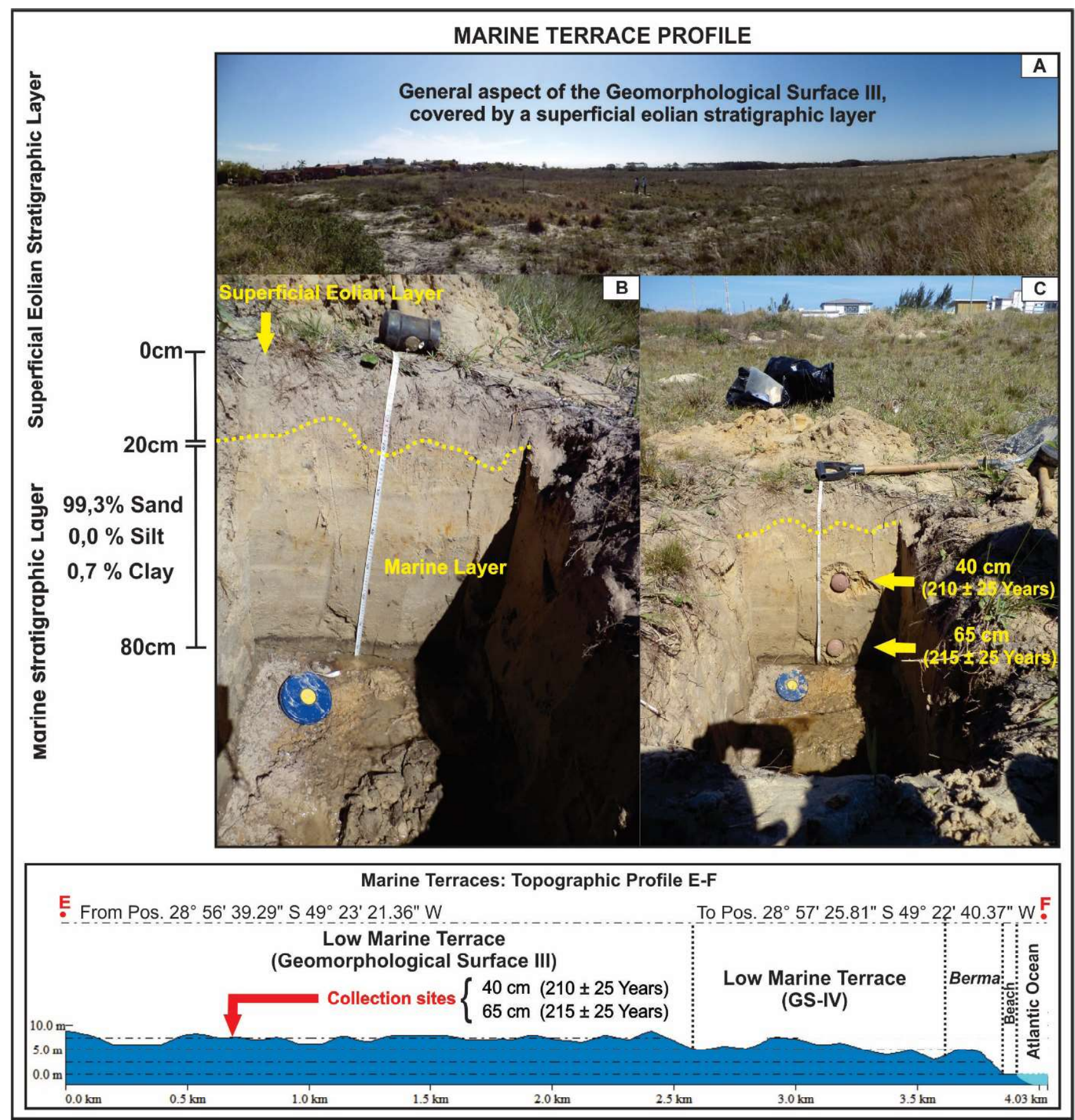

Figure 7 - Topographic Profile "E-F" of the marine terrace (GS-III) and collection site. A) General aspect of the marine terrace. B and C) Profile of stratigraphic layers, granulometric results, and ages of the deposits in the low marine terrace. 
Such low marine terrace (GS-III) features different morphological characteristics over its surface:

- Succession of ridges and pits between the Sombrio and Caverá lagoons to the West and shoreline to the East (Figure 8A). Regular, rectilinear, convex, wellpreserved coastal cords, and without wind reworking, which show the regressive barrier and coast prograde movements throughout the Holocene. Ridges have a maximum altitude of 9 meters. Pits are represented by elongated depressions filled by 1 meter of peat.
- Plain landing, softened towards the Atlantic Ocean approaching the Araranguá River to the North, just after the Caverá lagoon. Morphology imposed by superficial wind reworking, responsible for re-engaging the beach materials that make up the succession of ridges and pits with posterior spreading deposition over this levels throughout the Holocene, eliminating the rectilinear and convex continuity observed to the South (Figure 8B). Only this portion of marine terrace was dated due to its location, inserted within the limits of the Araranguá River Basin.

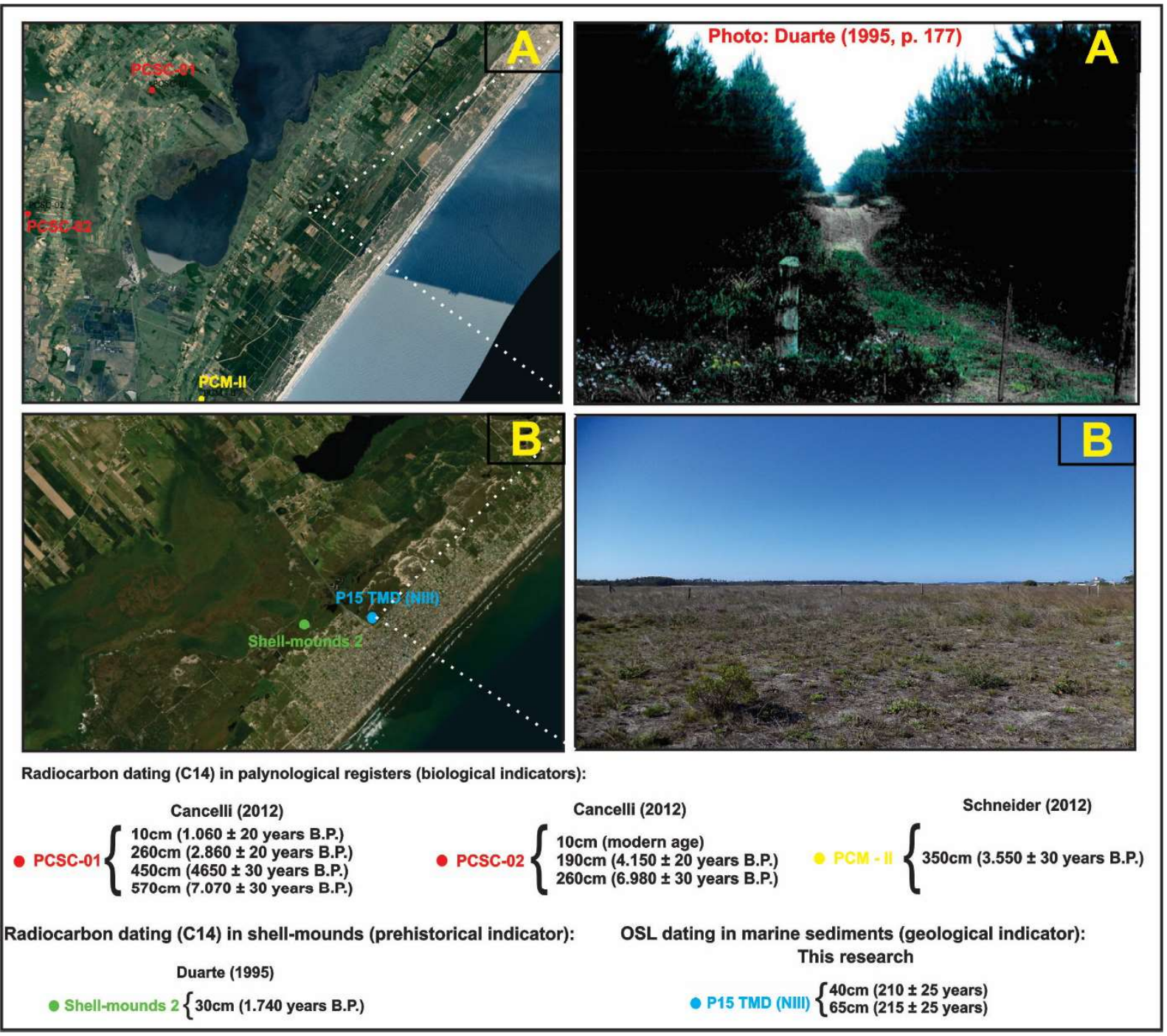

Figure 8 - Radiocarbon dating (C14) over the geomorphological surface III. A) Succession of ridges and pits between the Sombrio and Caverá lagoons to the West and shoreline to the East. B) Flat landing, softened towards the Atlantic Ocean approaching the Araranguá River to the North, just after the Caverá lagoon. Source: Duarte (1995), Cancelli (2012) and Schneider (2012)

The depositional events in question, associated with the production of this low terrace, are also related to the marine regression that succeeded the maximum Transgression of Santos (MIS1). Surface coverings feature very recent ages $(210 \pm 25 / 210 \pm 25$ years $)$ due to the location of the collection site - near the current shoreline and passage to the Geomorphological Surface IV. 


\section{Geochronology and Hydrodynamic Energy Conditions in Surface Coverings of Low Holocene Fluvial}

It is inferred that the sandy materials of this low marine terrace are similar to the marine sediments intrinsic to the low fluvial-marine terrace previously described (granulometric fractions and selection degree). Such uniformity reveals that homonym materials were housed during depositional events with similar hydrodynamic intensities.

Research results obtained through different dating methods in this geomorphological surface and its adjacent lagoons also revealed ages associated with a regressive eustatic episode that followed the 1e marine isotopic stage, interrupted for a period of relative sea level stabilization between $2.700 \pm 420$ and $2.250 \pm$ 300 years B.P.

We emphasize the results disclosed by Cancelli (2012) through radiocarbon dating $\left(\mathrm{C}^{14}\right)$ in palynological records (biological indicators) intrinsic to materials adjacent to the Sombrio lagoon (pit PSCS-01 and PSCS-02); Schneider (2012) by radiocarbon dating $\left(\mathrm{C}^{14}\right)$ in palynological records of swamp forests (biological indicators) and fluviallagoon deposits intrinsic to quaternary materials of the beach ridges and pits in question (pit PCM-II); Duarte (1995) through radiocarbon dating $\left(\mathrm{C}^{14}\right)$ in shell-mounds, mainly comprising Mesodesma Mactroides and Donax Hanleyanus (prehistoric indicators) over Holocene dune - a record completely destroyed in the present day; and OSL dating in quaternary sediments, conducted by this research (geological indicators).

The geomorphological surface IV (GS-IV) also corresponds to a low marine terrace with genesis in eustatic fluctuations raised by Holocene climatic pulsations ( $420 \pm 65$ and $165 \pm 35$ years B.P.). It also has a plain surface toward the Atlantic Ocean. The top is 5 meters high and the base is at 1 meter, next to the current shoreline. Materials covering this terrace are associated with Holocene depositional events. The materials show no signs of pedogenization and were classified as unconsolidated sandy-marine sedimentary deposits (Figure 9).

According to Suguio et al. (1985), the last evidence of a higher sea level than the current one refers to a small marine transgression observed between 2.800 and 2.500 years BP, in which a level from 1.5 to $2.5 \mathrm{~m}$ above the current one was reached and, ever since, there has been a tendency to continuously decrease. However, a small transgressive movement was verified in the study area between $420 \pm 65$ and $210 \pm 25$ years B.P., accompanied by a short stabilization of the relative sea level around $210 \pm 25$ and $165 \pm 35$ years B.P. Therefore, more recent than Suguio et al. (1985) expected.

Hence, the genesis of the formation of the marine terrace level IV is associated to the regression that followed this short stabilization of the relative sea level. Since then, the tendency of continuous decrease remained until the stabilization of the current sea level (165 \pm 35 years B.P to today). These Holocene eustatic movements will be better characterized in this research during the item regarding depositional events geochronology, linked to the production of low Holocene terraces.

\subsection{Textural classification of the surface coverings of the low terraces and hydrodynamic intensity during Holocene depositional events}

Textural classifications of the materials of layers and areas sampled were interpreted based on the proposal of Flemming (2000).

Samples were collected in superficial materials, disposed up to two meters deep, which were representative levels for the sample regarding the proposed objective since they are able to highlight and characterize more effectively the recent Holocene evolutive dynamics and depositional organizations of surface coverings through the ages obtained and the hydrodynamic energy intensity during the Holocene sedimentation, by granulometric analyses.

It should be noted that the depths of the collections were defined based on the outcrop of subsurface flow, which limited in some cases the performance of deeper collections (Table 4).

The recognition of the most representative granulometric frequencies for sampling was defined based on the depositional architecture of the analyzed profiles, which were, in general, homogenous. Thus, the analysis of sediments in the intermediate zone of the stratigraphic layers analyzed was prioritized, since there the mode is more representative, as they show the transition from the beginning to the end of Holocene depositional events. 


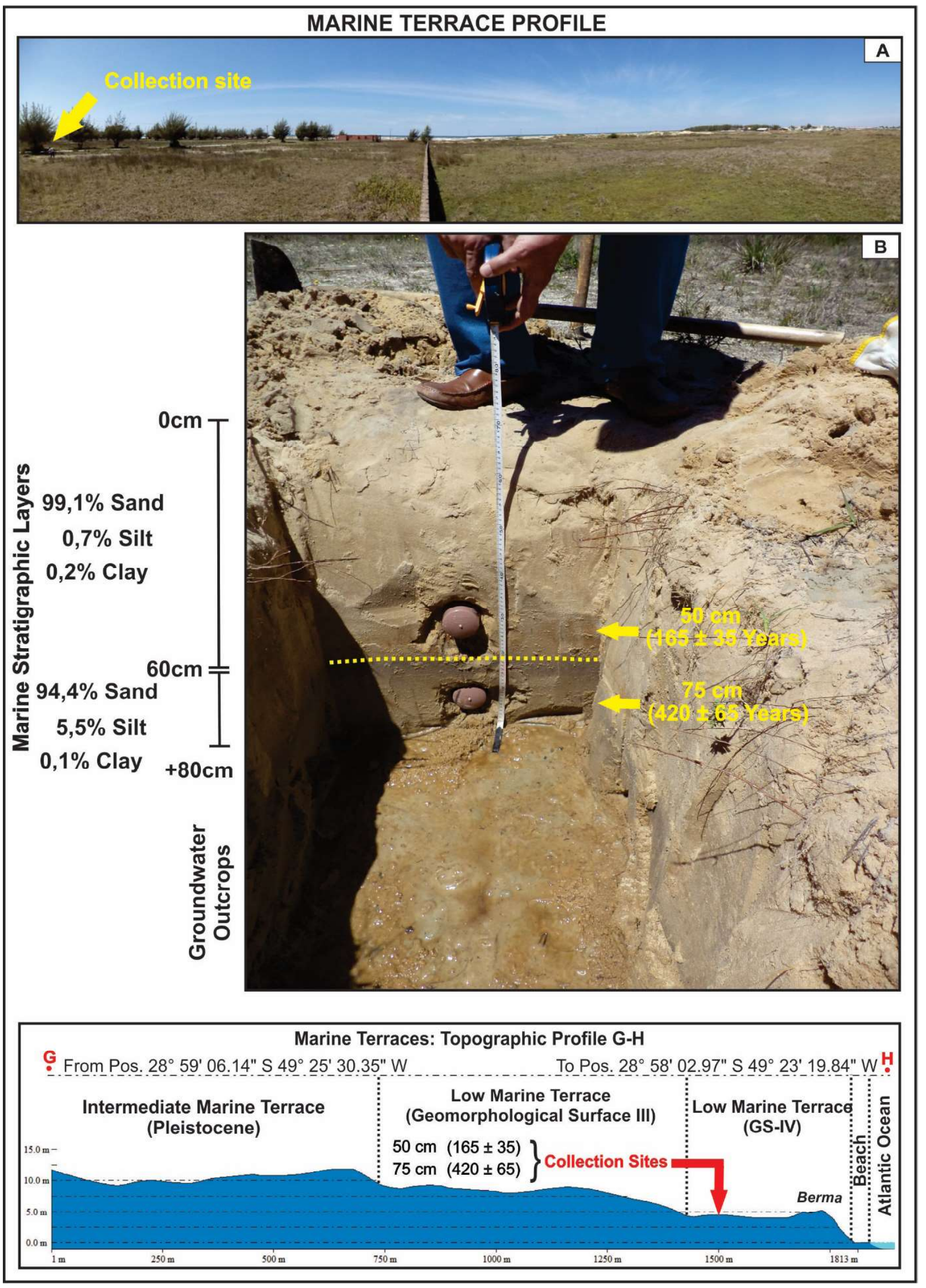

Figure 9 - Topographic Profile "G-H" of the marine terrace (GS-IV) and collection site. A) General aspect of the marine terrace. B) Profile of stratigraphic layers, granulometric results, and ages of the deposits in the low marine terrace. 
Table 4: Depth of sample collection and granulometric results of materials collected in surface coverings that make up the low marine, fluvial, and fluvial-marine terraces.

\begin{tabular}{|c|c|c|c|c|c|c|c|c|}
\hline \multicolumn{9}{|c|}{ Geomorphological Surface I } \\
\hline $\begin{array}{c}\text { Depth } \\
\text { (cm) }\end{array}$ & $\begin{array}{c}\text { Very } \\
\text { Coarse } \\
\text { Sand }(\%)\end{array}$ & $\begin{array}{c}\text { Coarse } \\
\text { Sand }(\%)\end{array}$ & $\begin{array}{l}\text { Medium } \\
\text { Sand (\%) }\end{array}$ & $\begin{array}{c}\text { Fine Sand } \\
(\%)\end{array}$ & $\begin{array}{l}\text { Very Fine } \\
\text { Sand (\%) }\end{array}$ & $\begin{array}{c}\text { Total } \\
\text { Sand } \\
(\%)\end{array}$ & $\begin{array}{l}\text { Silt } \\
\text { (\%) }\end{array}$ & $\begin{array}{l}\text { Clay } \\
(\%)\end{array}$ \\
\hline $60-80$ & 1.9 & 1.9 & 6.1 & 32.6 & 16.5 & 59.0 & 22.9 & 18.1 \\
\hline \multicolumn{9}{|c|}{ Geomorphological Surface II } \\
\hline $\begin{array}{c}\text { Depth } \\
\text { (cm) }\end{array}$ & $\begin{array}{c}\text { Very } \\
\text { Coarse } \\
\text { Sand }(\%)\end{array}$ & $\begin{array}{c}\text { Coarse } \\
\text { Sand }(\%)\end{array}$ & $\begin{array}{l}\text { Medium } \\
\text { Sand (\%) }\end{array}$ & $\begin{array}{c}\text { Fine Sand } \\
(\%)\end{array}$ & $\begin{array}{l}\text { Very Fine } \\
\text { Sand (\%) }\end{array}$ & $\begin{array}{c}\text { Total } \\
\text { Sand } \\
(\%)\end{array}$ & $\begin{array}{l}\text { Silt } \\
(\%)\end{array}$ & $\begin{array}{l}\text { Clay } \\
(\%)\end{array}$ \\
\hline $40-60$ & 0.0 & 0.0 & 3.6 & 31.1 & 5.4 & 40.1 & 29.0 & 30.9 \\
\hline $110-120$ & 0.0 & 0.0 & 8.9 & 82.1 & 4.0 & 95.0 & 1.6 & 3.4 \\
\hline $160-180$ & 0.0 & 0.1 & 6.8 & 87.4 & 4.8 & 99.1 & 0.5 & 0.4 \\
\hline \multicolumn{9}{|c|}{ Geomorphological Surface III } \\
\hline $\begin{array}{l}\text { Depth } \\
\text { (cm) }\end{array}$ & $\begin{array}{c}\text { Very } \\
\text { Coarse } \\
\text { Sand }(\%)\end{array}$ & $\begin{array}{c}\text { Coarse } \\
\text { Sand }(\%)\end{array}$ & $\begin{array}{l}\text { Medium } \\
\text { Sand (\%) }\end{array}$ & $\begin{array}{c}\text { Fine Sand } \\
(\%)\end{array}$ & $\begin{array}{l}\text { Very Fine } \\
\text { Sand (\%) }\end{array}$ & $\begin{array}{c}\text { Total } \\
\text { Sand } \\
(\%)\end{array}$ & $\begin{array}{l}\text { Silt } \\
(\%)\end{array}$ & $\begin{array}{l}\text { Clay } \\
(\%)\end{array}$ \\
\hline $35-45$ & 0.0 & 0.0 & 0.8 & 90.4 & 8.1 & 99.3 & 0.5 & 0.2 \\
\hline $65-70$ & 0.0 & 0.0 & 2.1 & 86.8 & 10.4 & 99.3 & 0.0 & 0.7 \\
\hline \multicolumn{9}{|c|}{ Geomorphological Surface IV } \\
\hline $\begin{array}{l}\text { Depth } \\
\text { (cm) }\end{array}$ & $\begin{array}{c}\text { Very } \\
\text { Coarse } \\
\text { Sand }(\%)\end{array}$ & $\begin{array}{c}\text { Coarse } \\
\text { Sand }(\%)\end{array}$ & $\begin{array}{l}\text { Medium } \\
\text { Sand (\%) }\end{array}$ & $\begin{array}{c}\text { Fine Sand } \\
(\%)\end{array}$ & $\begin{array}{l}\text { Very Fine } \\
\text { Sand (\%) }\end{array}$ & $\begin{array}{c}\text { Total } \\
\text { Sand } \\
(\%)\end{array}$ & $\begin{array}{l}\text { Silt } \\
(\%)\end{array}$ & $\begin{array}{l}\text { Clay } \\
(\%)\end{array}$ \\
\hline $40-50$ & 0.0 & 0.0 & 3.9 & 85.4 & 9.8 & 99.1 & 0.7 & 0.2 \\
\hline $50-75$ & 0.1 & 0.0 & 3.3 & 80.9 & 10.2 & 94.4 & 5.5 & 0.1 \\
\hline
\end{tabular}

In profiles containing successions of one or more stratigraphic layers, such as the fluvial-marine profile, individual samples were collected in each deposit. In profiles with no stratigraphic layers, we opted for collections in intermediate areas of trenches, close to the outcrop of subsurface flow.

GS-I surface coverings, corresponding to the low fluvial terrace, had $59 \%$ total sand, $22.9 \%$ silt, and $18.1 \%$ clay. It is important to emphasize that, in this surface, only one collection $(60-80 \mathrm{~cm})$ was performed due to the profile homogeneity. These materials were classified as muddy sand, with $41 \%$ mud content, and the correlated textural class was silty sand (Table 5), which are related to the fluvial hydraulic transport. Granulometric analyses revealed a high percentage of silt (22.9\%) and clay (18.1\%) when compared with predominantly sandy deposits from the marine hydraulic transport.

GS-II surface coverings, corresponding to the low fluvial-marine terrace, had different results (alluvial and marine materials). The superficial stratigraphic layer, 80-cm deep, is related to fluvial transport, with a high percentage of silt (29\%) and clay (30.9\%) in the sample collected between 60 and $80 \mathrm{~cm}$ of depth. These materials showed the sedimentary typology of sandy mud, with $59.9 \%$ mud content and a textural class indicative of clayey sandy mud (C-IV) (Table 5).

The intermediate stratigraphic layer, with around $80-140 \mathrm{~cm}$ of depth, is related to marine transport and has a high sand content $(95 \%$ in the sample collected between 60 and $80 \mathrm{~cm}$ deep. Such coarser sediments are separated from the alluvial surface layer by abrupt changes of color and texture, showing a sedimentary typology of slightly muddy sand and textural class correlated to slightly clayey sand (A-II), because of the higher rates of clay (3.4\%) when compared with silt (1.6\%), both amounting to $5 \%$ mud. This intermediate stratigraphic layer presents mottling, probably related to the proximity of the water table in past environments. Also, evidence of weatherized pebbles and shells are noted, characterizing a high-energy depositional environment, able to transport, deposit, and weatherize them. 
Table 5: Sediment types, mud content, and textural classes of surface covering in low marine, fluvial-marine, and fluvial terraces to the South of the Araranguá River, based on the methodological proposal of Flemming (2000).

\begin{tabular}{c|c|c|c|c|c}
\hline $\begin{array}{c}\text { Geomorphological } \\
\text { Surfaces }\end{array}$ & Depth & Code & Type of Sediment & $\begin{array}{c}\text { Mud } \\
\text { content (\%) }\end{array}$ & Textural class \\
\hline $\begin{array}{c}\text { Fluvial Terrace } \\
\text { (GS-I) }\end{array}$ & $60-80$ & B-II & Muddy sand & $25-50 \%$ & Silty sand \\
\hline $\begin{array}{c}\text { Fluvial-Marine } \\
\text { Terrace }\end{array}$ & $40-60$ & C-IV & Sandy mud & $50-75 \%$ & Clayey sandy mud \\
(GS-II) & $110-120$ & A-II & Slightly muddy sand & $5-25 \%$ & Slightly clayey sand \\
Sand
\end{tabular}

The deepest stratigraphic layer, underlying the previous ones, with depth between 140-200 cm, also relates to marine transport. These materials showed the sedimentary typology of sand $(99.1 \%), 0.9 \%$ mud content and a textural class indicative of sand (S). One can correlate the higher amount of mud in the intermediate layer $(80-140 \mathrm{~cm})$ in comparison with the underlying one $(140-200 \mathrm{~cm})$ with leaching processes acting over alluvial sediments of surface coverings, responsible for transporting part of the fines in depth, accumulating them on the intermediate depositional layer.

GS-III surface coverings, corresponding to the low Holocene marine terrace, presented an overlay of stratigraphic layers from eolian and marine transport.

The superficial sedimentary pack corresponds to eolian materials, with thickness ranging from 15 to $25 \mathrm{~cm}$, related to the spreading of dunes parallel to the shoreline and remobilization of beach materials. Granulometric analyses and OSL dating were not carried out in these materials due to the fact their depositional specificity is not exclusively linked to hydraulic transport.

The underlying stratigraphic layer, related to marine hydraulic transport, has a high percentage of sand $(99.3 \%)$ in samples collected between $35-45 \mathrm{~cm}$ and $65-70 \mathrm{~cm}$, as well as low rates of silt $(0.5 \%$ and $0.2 \%$ ) and clay ( 0.0 and $0.7 \%$ ). These materials showed the sedimentary typology of sand $(99.3 \%), 0.7 \%$ mud content, and a textural class indicative of sand (S).

GS-IV surface coverings, corresponding to a low marine terrace, presented similar characteristics to those of marine materials of the low fluvial-marine (GS-II) and marine (GS-III) terraces, but with a different stratigraphic organization. The surface layer, represented by $60-\mathrm{cm}$ deep, has a high percentage of sand $(99.1 \%)$ in the sample collected between $40-50 \mathrm{~cm}$ of the profile. These materials featured a sedimentary typology of sand, with $0.9 \%$ mud content $(0.7 \%$ silt and $0.2 \%$ clay) and textural class of sand.

The underlying stratigraphic layer, with 60-80 $\mathrm{cm}$ depth, also relates to marine transport, and the high percentage of sand $(94.4 \%)$ in the sample collected $50-75 \mathrm{~cm}$ deep is an evidence of such process. Such materials, based on the methodological proposal of Flemming (2000), presented a sedimentary typology of slightly muddy sand and the textural class correlates to slightly silty sand (A-I), on the basis of the higher rate of silt (5.5\%) when compared to clay $(0.1 \%)$, which amount to $5.6 \%$ of mud. These sediments are separated from the surface layer by gradual changes in color and texture. The slight increase of mud in the deepest stratigraphic layer when compared to the surface marine depositional layer can also be correlated to leaching processes on the superficial sediments.

Results of granulometric analyses, plotted on the Flemming's diagram (2000), made it possible to distinguish hydrodynamic flows of higher and lower energy (Figure 10). It is observed that samples of the surface coverings of fluvial, fluvial-marine, and marine terraces are distributed over four distinct areas on the ternary textural diagram of Flemming (2000). 


\section{Flemming Textural Diagram (2000) Surface coverings of Holocene Low Terraces of the Araranguá River Basin (SC)}
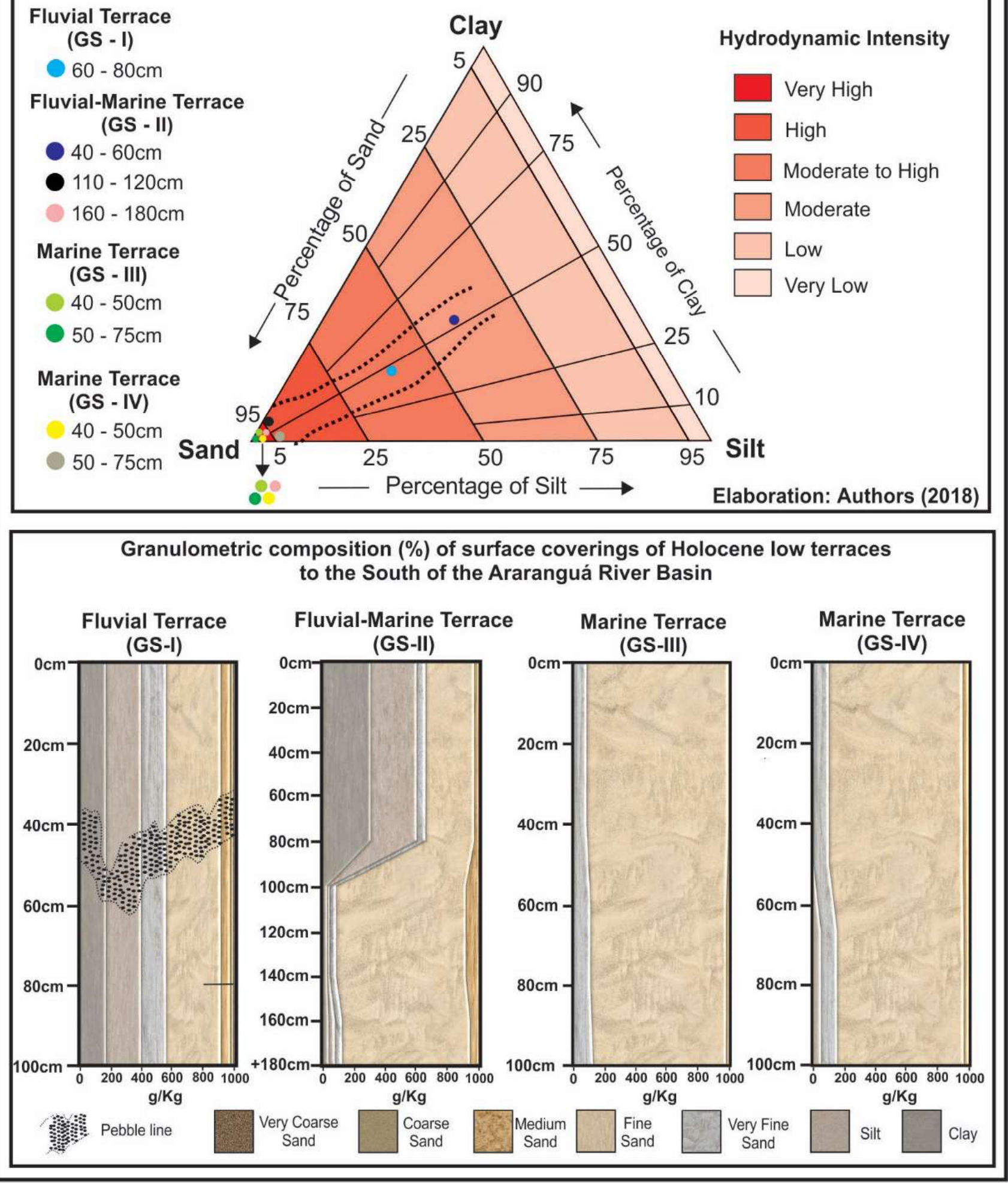

Figure 10 - Distribution of the samples of surface coverings of fluvial, fluvial-marine, and marine terraces of the studied area over four distinct areas of the ternary textural diagram of Flemming (2000), associated with very high, high, moderate-to-high, and moderate energy intensities during Holocene fuvial and marine depositional events. Granulometric composition profiles (\%) of the surface coverings. 
The surface coverings of the fluvial terrace and the superficial alluvial materials of the fluvial-marine terrace that had the highest mud contents represented the smaller hydrodynamic energy flows of transport when compared with marine deposits. However, percentages of sand $(59.0 \%$ and $40.1 \%)$ also indicate high hydrodynamic energy conditions for fluvial systems (moderate and moderate to high), a fact correlated with the presence of pebbles and gravel linked to the erosion of basalts of the Serra Geral formation and of sandstone of Palmas, Gramado, and Botucatu formation.

Surface coverings of marine terraces and underlying marine sandy materials of alluvial deposits of the fluvial-marine terrace showed low levels of mud and high levels of sand fraction, representing high-intensity hydrodynamic energy flows (high and very high).

The good selection of marine sediments in the Araranguá oceanic plain is related to the action of waves, which break in the Surf zone and promote high material reworking, moving toward the coast with increasing strength. In such dynamic, part of the coarser sediments (sand) are deposited on the beach. During the retreat, the waves return slowly toward the Atlantic Ocean, carrying them along with the fines and storing them on the ocean floor. These observations were carried out in the field.

Such results provided subsidies for the geochronological reconstruction of Holocene depositional events of the surface covering of low terraces.

\section{Discussions}

\subsection{Geochronology of depositional events linked to the production of Holocene low terraces}

Villwock (1984) identified, in the coast of Rio Grande do Sul, four generations of marine terraces, indicating paleo-levels above the current sea level, which were drawn from the lagoon-barrier dynamics. The barrier-lagoon system I registers a marine incursion 420.000 years B.P. (MIS11c). The second-last transgression observed by the barrier-lagoon system II was 325.000 years ago (MIS9e), being identified in the Brazilian coast by Bittencourt et al. (1979), in a pioneer way, through inactive cliffs of the barrier formations in northeastern Brazil. The barrier-lagoon system III shows a higher sea level than the current one at 120.000 years B.P. (MSI5e), which was identified in the Brazilian coast, in a pioneer way, by Suguio and Martin (1978) on the coast of the State of São Paulo (Cananeiense Transgression) and by Bittencourt et al. (1979) in the coasts of the State of Bahia, Alagoas, Sergipe, and Pernambuco (Ancient Transgression). Also, the barrierlagoon system IV lists the last transgressive phase 5.500 years ago (MIS1), which is known as Transgression of Santos (Suguio et al. 1985; Martin et al., 1996) or Last Transgression (Bittencourt et al. 1979, Kowsmann et al., 1977; Corrêa, 1979, 1996).

Regarding the southern coast of Santa Catarina, systems I and II have already been completely covered by the development of alluvial-colluvial deposits and coalescence of extensive alluvial fans with direction NW-SE, developed because of the erosion of Gondwana sedimentary rocks in plateau edge positions in the Serra Geral. In addition to this factor, in comparison with the coast of Rio Grande do Sul, is the greater proximity between the coast of Santa Catarina and the plateau escarpment located West, reflection of the rifting that gave rise to the Pelotas Sedimentary Basin (RS).

The evolution of the southern coast of Santa Catarina can be then explained on the basis of the development of Lagoon-Barrier systems III and IV, responsible for producing the current morphological configuration of the Araranguá River Basin, which would be linked to the evolutionary proposal of Villwock (1984) and Villwock and Tomazelli (1998) for the southern coastal strands of Rio Grande do Sul.

In the study areas, the Lagoon-Barrier system I is represented by a Pleistocene paleo-lagoon to the West, parallel to Pleistocene marine terraces (barrier) produced 120.000 years B.P and currently covered by fossil dunes. The Lagoon-Barrier system IV consists of a paleo-lagoon parallel to the ancient shoreline, partially collimated, where currently several Holocene lagoons (Caverá, Sombrio, Dourada and Serra) and turfy and paludal sediments coexist, associated with the succession of Holocene beach and eolian deposits in the extreme East of the basin, adjacent to the current coast line, with altitudes ranging from 10 to 1 meter, corresponding to the Transgression of Santos (MIS1e).

These Holocene beach deposits inserted in the Lagoon-Barrier system IV of Villwock (1984) are represented by the surface coverings described in this research and make up the low Holocene terraces evidenced (GS-II, GS-III and GS-IV). Therefore, the 


\section{Geochronology and Hydrodynamic Energy Conditions in Surface Coverings of Low Holocene Fluvial}

geochronological reconstruction performed at this point is limited to this set of Holocene coastal strands and alluvial deposits overlapping and, due to the objective initially proposed, which includes the verification of occurrence of Holocene climatic pulsations and consequent prograde and retrograde movements of the ocean coast due to Holocene eustatic fluctuations of the relative sea level.

Such evolutionary proposal is based, therefore, on dating of surface coverings of Holocene fluvial, fluvial-marine, and marine terraces; morphology of geomorphological surfaces linked to transgressions and regressions; granulometric tests; field work; characterization of the analyzed profiles and inferences on the climatic pulsations responsible for the eustatic movements based on the acquired data, geochronological register of other research along the Brazilian coast, and correlation with theories of Holocene global cooling proposed by the international morphoclimatic literature.

\subsection{Climate pulsation I $(5.000 \pm 620$ to $6.000 \pm 820$ Years B.P.)}

The Holocene transgressive peak (MIS1), reached about 5.500 years ago, provoked the retreat of the Araranguá river mouth and enabled the formation of a transgressive barriers consisting of beach and eolian sands. In accordance with the research of Villwock et al. (1984), Villwock and Tomazelli (1998) and Tomazelli and Villwock (2000), these barriers, installed at the transgressive maximum due to the high availability of sandy sediments in the internal continental platform, laterally prograde during the regressive phase that followed, depositing marine materials (beach quartz sands, of fine to very fine grains) through the construction of regressive coastal strands that were later remobilized and superficially spread, giving rise to the geomorphological surface III.

Possibly, such marine regression, in addition to the deposition of dated surface coverings $(6.000 \pm 820$ and $5.000 \pm 620$ Years), is associated with the third cycle of Holocene global cooling proposed by Bond et al. (1997, 2001) and Wanner et al. (2011) between 4.600-4.800 years B.P., which may have influenced the beginning of this descending eustatic movement, culminating in the determination of the current sea level. Wanner et al. (2011) identified negative temperature anomalies on Greenland, North America, and Antarctica, whereas in South America the negative temperature, humidity, and precipitation anomalies predominate, which are correlated with the beginning of a drier period determined by this research for the southern coast of Santa Catarina $(5.000 \pm 620$ and $6.000 \pm 820$ years B.P.), and a drier continental phase (4.600-5.300 years B.P) determined by Dias and Perez Filho (2015b) through OSL dating in surface coverings of the Urucaia Planation Surface in the State of São Paulo.

Radiocarbon $\left(\mathrm{C}^{14}\right)$ dating results in shell-mounds and palynological records carried out by Duarte (1995), Cancelli (2012), and Schneider (2012) suggest progressive continuation of this marine regression, with moments of stabilization over the years, revealing more recent ages in this geomorphological surface (GS-III) to the extent that areas closer to the current shoreline were dated $(4.150 \pm 20 / 3.550 \pm 30 / 1.740 \pm 25$ years B.P.). The dating carried out by this research in the bottom edge of this marine terrace showed age of 210 \pm 25 years B.P., a result that confirms and reinforces such interpretations.

Such marine depositional event acted upon high and very high hydrodynamic intensities in the estuarine paleo-regime of the dated sites. The high energy capacity is confirmed by the evidence of weathered pebbles within the marine materials contained in the profile of the fluvial-marine terrace (GS-II).

\subsection{Climatic Pulsation II (2.700 \pm 420 to $2.250 \pm 300$ years B.P.)}

In the southern coast of Santa Catarina, we infer that the regressions started around $6.000 \pm 820$ years B.P. progressively acted up to $2.700 \pm 420$ years B.P., when the relative sea level would have stabilized, thus remaining until $2.250 \pm 300$ years A.P. This interpretation is supported by the age of the alluvial materials and the morphological characteristics of the fluvial-marine plain, where the GS-II sample was collected.

Therefore, throughout the marine regression that followed the transgressive peak of Santos $(6.000$ \pm 820 to $2.700 \pm 420$ years B.P.), the Araranguá river started once again to drain the areas previously submersed by the MIS1 (17.000 to 5.500 years B.P.), vertically dissecting the low marine terrace (GS-III) and separating it in fragments to the North and South of the river. In this period, the elevation of gradient in 
the lower course of the river occurred, in response to a greater incision of the thalweg due to remounting erosion, caused by the demotion of the general base level. As one can see in the strand between the dated collection sites, regarding low fluvial and fluvial-marine terraces (Figure 4) - which do not have current evidence indicating paleochannels, this dynamic is responsible for eliminating part of the intricacies and impose new paths with less meandering.

In the stabilization period of the relative sea level $(2.700 \pm 420$ to $2.250 \pm 300$ years B.P.), associated with the installation of a drier continental climate, probably the formation of the low fluvial terrace occurred through the lateral development of plains and the production of stepped levels and slopes toward the watercourse, as well as the deposition of alluvial materials in continental areas that were not affected by the MIS1 transgressive peak. During such dynamics, the low marine terrace (GS-III) was laterally dissected and the alluvial materials were deposited toward the coast, advancing on marine sediments and resulting in the dated fluvialmarine terrace (GS-II).

Through the interpretation of the map of surface coverings spatialization (Figure 4), one can check the horizontal enlargements of the fluvial-marine plain in this strand, linked to the abandonment of several paleochannels. Such dynamics possibly comes from the sea level stabilization, which promotes the lateral migration of the Araranguá river in its old mouth, probably caused by the influence of tidal reflux. Current dynamics observed in the Araranguá river mouth.

This drier continental stage $\mathbf{( 2 . 7 0 0} \pm \mathbf{4 2 0}$ to $\mathbf{2 . 2 5 0}$ $\pm \mathbf{3 0 0}$ years B.P.), linked to the deposition of Holocene alluvial materials, corresponds to the fourth Holocene global cooling period (2.600-2.800 years B.P.) identified by Bond et al. $(1997,2001)$ and Wanner et al. (2011). The results disclosed by Behling (1995), Thomas and Thorp (1995), Pessenda (1996), Stevaux (2000), Dias and Perez Filho (2015a), and Storani (2015) also point to a drier continental stage during the period established by this research.

Possibly, the horizontal evolution and lateral development of fluvial marine plain in this lower river course were accomplished by mechanical disaggregation, and the deposition of alluvial surface coverings would have occurred during the sporadic torrential rains throughout the dry continental phase, which probably came from the continental interior, where the plateau escarpment with more than $1.200 \mathrm{~m}$ altitude is located.

Such interpretation is supported by the similarity between characteristics of alluvial surface coverings arranged on the low fluvial and fluvial-marine terraces and the materials from the plateau edge and from alluvium-colluvial deposits of alluvial fans at the base of the upstream escarpment until near the ocean plain, where they dive underneath the marine sediments from the Upper Pleistocene and Holocene, detailed by Duarte (1995), Pontelli and Pellerin (1998), Krebs (2004), Dantas et al. (2005), Pontelli (2005), and Horn Filho et al. (2014).

In this case, the sedimentary sandy-clayey to clayey-sandy facies within the alluvial materials dated by this research suggest proximal parts environment of averaged of alluvial fans. They are associated with dissection processes and fluvial transportation of alluvium-colluvial deposits in regressive periods of the relative sea level. The alluvial gravel disposed in the fluvial terrace, comprising pebbles and rolled subrounded blocks (present in long stretches of the alluvial fans) from residual sandstone elevations of the Rio do Rastro formation and basalt from the Serra Geral formation, also confirm this hypothesis.

High percentages of sand in alluvial deposits are also linked to the erosion of Gondwana sedimentary rocks in a plateau edge position (K1 $\alpha \mathrm{pa}, \mathrm{K} 1 \beta \mathrm{gr}$, $\mathrm{J} 3 \mathrm{~K} 1 \mathrm{bt}$ ). These rocks are the sandstone of Palmas, Gramado, and Botucatu formations, which, when weathered, can form grains of sand. The geological map of Wildner et al. (2014), in a mapping conducted by the Mineral Resources Research Company (CPRM), illustrates such situation.

Thus, changes in the general base level and constant readjustments of the watercourse throughout the Lower Miocene, Pliocene, Pleistocene, and Holocene, linked to erosive resumptions of the plateau escarpment, imposed to the rivers the indentation, recoil, and profile of the escarpment front, at the same time that eroded the underlying materials of origin and created alluvial fans. Eroded materials were transported by the river toward the downstream or rolled down to the escarpment base, resulting in talus and colluvial deposits, as well as correlative alluvial materials (alluvial fans). Many of these sediments, depending on the transport energy 


\section{Geochronology and Hydrodynamic Energy Conditions in Surface Coverings of Low Holocene Fluvial}

capacity, in addition to paleoclimatic conditions, may have been transported along extensive river routes, being deposited in arts of the lower course, as verified in the low fluvial and fluvial-marine terraces.

In this perspective, Flemming (2000) warns about the possibility of arguing that the composition of a sediment would merely concern source-related characteristics, which would exclude the interpretative viability associated with the selection of materials under different hydrodynamic energy conditions. However, at the same time that Flemming (2000) considers the influenced of origin material on the mineralogical and textural composition of fluvial sediments, Flemming (2000) and Bagnold (1968) point out that is also true that any size spectrum of the source-controlled grains would also be subjected to size screening throughout the hydraulic transport, which would thus result in a selected deposition along an energy gradient.

It should be noted that the depositional event related to these alluvial materials (2.700 \pm 420 to 2.250 \pm 300 years B.P.) occurred under high hydrodynamic energy conditions considering fluvial systems (moderate and moderate to high), able to transport the identified set of blocks, pebbles, and gravels. The hydrodynamic intensity was stronger in the surface coverings of the fluvial terrace (GS-I) due to the greater gradient and proximity of the upstream alluvial fans in comparison with the alluvial sediments of the low fluvial-marine terrace (GS-II), an environment that refers to the gradation of moderate intensity due to the proximity to the general base level, which was stabilized in this period.

\subsection{Climatic Pulsation III (420 \pm 65 to $215 \pm 25$ years B.P.)}

The regressive eustatic movement started after the transgressive peak of Santos (MIS1), interrupted by a period of relative sea level stabilization $(2.700 \pm 420$ to $2.250 \pm 300$ years B.P.), progressively continued until $420 \pm 65$ years B.P. After this period, a small marine transgression ( $420 \pm 65$ to $210 \pm 25$ years B.P.) was verified, based on OSL dating, accompanied by a short stabilization of the relative sea level around $210 \pm 25$ to $165 \pm 35$ years B.P. Since then, a tendency of continuous demotion arose until the stabilization of the current sea level (165 \pm 35 years B.P. to the present).

Such interpretations are supported by the older ages revealed in materials found in a greater depth $(65$ $\mathrm{cm}$ and $75 \mathrm{~cm}$ ) in GS-IV profiles, when in comparison with GS-III. The collection of sediments housed under $65 \mathrm{~cm}$ depth at the end of GS-III, situated in a higher altimetric level $(7.5 \mathrm{~m})$, farther from the current shoreline $(944 \mathrm{~m})$, revealed a more recent depositional event ( $215 \pm 25$ years B.P). The collection of sediments housed under $75 \mathrm{~cm}$ depth at the beginning of GS-IV, situated in a lower altimetric level $(4.5 \mathrm{~m})$ and closer from the current shoreline $(280 \mathrm{~m})$, revealed an older depositional event $(420 \pm 65$ years B.P). While surface materials $(40 \mathrm{~cm}$ and $50 \mathrm{~cm}$ ) showed geochronological consistency due to the altimetric decrease and rapprochement with the current relative sea level (215 \pm 25 and $165 \pm 35$ years B.P.).

Based on the acquired data, it was verified that the stratigraphic layer underlying the profile analyzed in the GS-IV indicates an extension of the regressive movements of the sea up to $420 \pm 65$ years B.P., which was followed by a short marine transgression until 210 \pm 25 years B.P., responsible for re-mobilizing the dated materials of GS-III ( $215 \pm 25$ and $210 \pm 25$ years B.P.). Such remobilization exposed the marine sediments, which were buried since the last regression (up to $420 \pm$ 65 years B.P.), to sunlight again. With that, the emission of energy from sunlight released the electrons trapped in crystalline solids, reducing the OSL signal to zero. From this moment, the electron and the crystalline quartz network were once again subjected to ionizing radiation, thus accumulating new OSL signals (215 \pm 25 and $210 \pm 25$ years B.P.).

Later, between the dated areas (GS-III and GSIV), a period associated with the short stabilization of relative sea level was established, evidenced by the continuous ramp that morphologically separates the geomorphological surfaces III and IV (topographical profiles), which was drawn up by the waves along this ancient shoreline and also provided subsidies for these interpretations.

Finally, after a stabilization phase, a progressive descent until the current sea level started, which was responsible for producing the superficial stratigraphic layers of GS-IV (165 \pm 35 years B.P.) that cover the underlying materials deposited during the regression that ended about $420 \pm 65$ years B.P.

Possibly, the start of this short marine transgression ( $420 \pm 65$ to $210 \pm 25$ years B.P.) is linked to the end of the sixth cycle of Holocene global cooling proposed 
by Bond et al. (1997, 2001) and Wanner et al. (2011), between $650-450$ years B.P., known by the national and international literature as Little Ice Age (Matthews and Briffa, 2005; Mann et al., 2009; Trouet et al., 2009). This climatic event is correlated, according to Wanner et al. (2011), to strong tropical volcanic eruptions and smaller solar activity, which triggered the slowdown of thermohaline circulation in the Atlantic. Wanner et al. (2011) observed, from the correlation of these data, a predominance of negative temperature anomalies for the Norther Hemisphere, whereas in the southern Brazil medium anomalies prevailed.

In this perspective, the end of the regressions that lasted until $420 \pm 65$ years B.P. is associated with the end of the Little Ice Age/sixth Holocene global cooling cycle (650-450 years B.P.). Thus, the short transgression the followed this regressive event represents the transition between a drier phase of the Little Ice Age and the resumption/start of humidity conditions similar to the present. In particular it highlights the response of the environmental system to the instability caused by Holocene climatic pulsations.

The influence of the transition from the Little Ice age to the current wet climate on the production of Holocene terraces in Brazil was researched by Storani (2015), Storani and Perez Filho (2015) and Souza and Perez Filho (2015). The authors identified the production of low fluvial terraces in rivers located in the Western Plateau of São Paulo (Pardo and Turvo: $740 \pm 100 / 560 \pm 80 / 540 \pm 75$ years B.P.) and the Peripheral Depression of São Paulo (Mogi Guaçu, Capivari, Corumbataí, Piracicaba and Araquá: $720 \pm$ $100 / 710 \pm 90 / 700 \pm 110 / 630 \pm 75 / 590 \pm 70$ years B.P.) during the interval associated with the Little Ice Age (650-450 years B.P.), in a drier climate phase than the present in the State of São Paulo.

Similarly, Dias and Perez Filho (2015a) and Storani (2015) dated recent alluviums deposited along the flooding plains of rivers within the Western Plateau (São José dos Dourados) and Peripheral Depression of São Paulo (Corumbataí, Capivari and Itapetininga). Dating results revealed more recent ages than 450 years B.P. $(370 \pm 50 / 310 \pm 40 / 300 \pm 45 / 250 \pm 45 / 200 \pm 40$ $/ 150 \pm 25$ years B.P.), suggesting a correspondence with environmental characteristics of humidity similar to the current ones. This because recent alluvial materials have the same characteristics of sediments currently transported by rivers and indicate depositions under climate and energy conditions that are similar to the ones we have today.

As well as this research, studies mentioned in the previous paragraphs were significantly consistent with the study area since they managed to chow the resumption of humidity conditions that remain until today, at the same time that revealed how recent is the surface organization and configuration of tropical landscapes, both in coastal as in continental areas, often commanded by Holocene climatic pulsations.

Marine depositional events linked to this climatic pulsation acted under high and very high hydrodynamic energy intensities in the estuarine paleo-regime of the dated areas. We assume that the hydrodynamic intensity was much stronger (very high) in materials deposited during the short transgression, relates to the remobilization of surface coverings of the end of GS-III, whereas the GS-IV materials, accommodated during regressive eustatic movements, showed slightly decrease in hydrodynamic energy capacity (high).

\section{Conclusions}

The results presented, plotted on Flemming's diagram (2000), made it possible to distinguish higher and lower energy flows. Surface coverings of the low fluvial terrace (GS-I) and the alluvial materials of the low fluvial-marine terrace (GS-II) presented the higher mud contents among all samples, which was correlated with moderate and moderate to high hydrodynamic energy transport flows. On the other hand, surface coverings of marine terraces (GS-III and GS-IV) and the marine sandy materials underlying alluvial deposits of the fluvial-marine terrace showed low levels of mud and high levels of sand fraction, representing high- and very high-intensity hydrodynamic energy flows.

Optically Stimulated Luminescence (OSL) technique was used in the materials collected from the analyzed profiles, showing the absolute ages of recent depositional events, responsible for transporting the materials in question and by the current spatial configuration of surface covering. Dating results provided subsidies for the Holocene evolutionary interpretation from the latest exposure of materials to sunlight. The ages obtained were integrated to analysis based on Holocene climatic pulsation, correlated to marine transgression and regression episodes, responsible for the production of terraces and 
specialization of Holocene surface coverings.

Absolute ages of surface coverings corresponded to climatic events of switch between hot-dry/hot-wet environments and to global cooling periods identified by Bond et al. (1997, 2001) and Wanner et al. (2011). Three Holocene climatic pulsations were identified, which were determinants for the surface organization of the landscape in the lower course of the Araranguá river and the oceanic plain of its river basin through the production of low fluvial, fluvial-marine, and marine terraces, as well as deposition and spatialization of surface coverings that make them up.

- Climatic pulsation I $(\mathbf{6 . 0 0 0} \pm \mathbf{8 2 0}$ to $5.000 \pm 620$ Years B.P.), linked to the transgressive peak of Santos (MIS1) and to the end of the climate optimal; passage to a drier stage than the current one, linked to the third cycle of Holocene global cooling between 4.600-4.800 years B.P. (Bond et al. 1997, 2001; Wanner et al. 2011); start of the marine regression that succeeded the transgressive peak of Santos, beginning of GS III developments, and deposition of marine stratigraphic layers intrinsic to the low fluvial-marine terrace (GS-II);

- Climatic Pulsation II (2.700 \pm 420 to $2.250 \pm 300$ years B.P.), associated with the relative sea level stabilization during the Upper Holocene and installation of a drier continental climate than the current one, correlated with the fourth Holocene global cooling between 2.600-2.800 years B.P. (Bond et al. 1997, 2001; Wanner et al. 2011); GS I development, and deposition of alluvial sediments on GS-II marine materials;

- Climatic pulsation III $(420 \pm 65$ to $215 \pm 25$ years B.P.), linked to a short eustatic transgressive movement in the Upper Holocene that interrupted the tendency of continuous demotion started $2.250 \pm 300$ years ago; transition from a drier phase than the current one, correlated with the end of the sixth Holocene global cooling cycle/Little Ice Age between 650-450 years B.P. (Bond et al. 1997, 2001; Wanner et al. 2011) for the resumption/start of humidity conditions similar to the present ones; end of GS-II production during the short stabilization of relative sea level $(210 \pm 25$ to $165 \pm 35$ years B.P.) and start of GS-IV formation throughout the regression that followed $(165 \pm 35$ years B.P until today), culminating in the current relative sea level.

The marine depositional event $(6.000 \pm 820$ to $5.000 \pm 620$ Years B.P) acted upon high and very high hydrodynamic intensities in the estuarine paleo-regime throughout the climatic pulsation I. The depositional event linked to the climatic pulsation II, referring to alluvial materials, occurred under high hydrodynamic energy conditions for fluvial systems (moderate and moderate to high), able to transport the identified set of blocks, pebbles, and gravel. Hydrodynamic intensity was stronger in the surface coverings of the fluvial terrace (GS-I) when compared with the alluvial sediments of the low fluvial-marine terrace (GS-II).

Marine depositional events linked to the climatic pulsation III also acted under high and very high hydrodynamic energy intensities. Hydrodynamic intensity was stronger (very high) in materials deposited during the short transgression, related to the remobilization of surface coverings of the end of GS-III, whereas GS-IV materials, accommodated during the regressive eustatic movements, showed a small decrease in hydrodynamic energy capacity (high).

\section{Acknowledgments}

We express our thanks to FAPESP (São Paulo Research Foundation) by the research funding through the Processes 2016/05327-6 and 2016/08944-6. The authors thank Espaço da Escrita - Pró-Reitoria de Pesquisa - UNICAMP - for the language services provided.

\section{References}

ALVES, N. S. Mapeamento hidromorfodinâmico do complexo fluvial de Anavilhas. Contribuição aos estudos de geomorfologia fluvial de rios amazônicos. Tese (Doutorado em Geografia), Faculdade de Filosofia, Letras e Ciências Humanas, Departamento de Geografia, Universidade de São Paulo, São Paulo. 2013. 214f.

ANGULO, R. J.; LESSA, G. C. The Brazilian sea-level curves: a critical review with emphasis on the curves from the Paranaguá and Cananéia regions. Marine Geology, v. 140, p.141-166, 1997.

ANGULO, R. J.; SUGUIO, K. Re-evaluation of the Holocene sealevel maxima for the State of Parana, Brazil. Palaeogeography, Palaeoclimatology, Palaeoecology, v. 113, p.385-393, 1995.

BAGNOLD, R. A. Deposition in the process of hydraulic transport. Sedimentology, v.10, p.45-5, 1968.

BEHLING, H. A higth resolution Holocene pollen record from lago do Pires, SE Brazil: vegetation, climate and fire history. J. Paleolim., v.14, p.253-268, 1995.

BEHLING, H. South and southeast Brazilian grasslands 
during Late Quaternary times: a synthesis. Paleogeography, Palaeoclimatology, Palaeoecology, v.177, p.9-27, 2002.

BERGER, A. Long-term variations of daily insolation and Quaternary climate changes. J. Atmos. Sci., v.35, p.2362-2367, 1978.

BIANCHI, G. G.; MCCAVE, I. N. Holocene periodicity in North Atlantic climate and deep ocean flow south of Iceland. Nature, v.397, p.515-517, 1999.

BITTENCOURT, A. C. S. P.; MARTIN, L.; VILAS-BOAS, G. S.; FLEXOR, J. M (1979). The marine formations of the coast of the State of Bahia, Brazil. In: SUGUIO, K.; FAIRCHILD, T. R.; FLEXOR, J. M. (Org.) International Symposium on Coastal Evolution in the Quaternary. $1^{\text {a }}$ ed. São Paulo: Proceedings, São Paulo, Instituto de Geociências, 1979, p. 232-253.

BOND, G.; SHOWERS, W.; CHESEBY, M.; LOTTI, R.; ALMASI, P.; MENOCAL, P.; PRIORE, P.; CULLEN, H.; HAJDAS, I.; BONANI, G. A pervasive millennial-scale cycle in the North Atlantic Holocene and glacial climates. Science, v.294, p.2130-2136, 1997.

BOND, G.; KROMER, B.; BEER, L.; MUSCHELER, R.; EVANS, M. N.; SHOWERS, W.; HOFFMANN, S.; LOTTIBOND, R.; HAJDAS, I.; BONANI, G. Persistent solar influence on North Atlantic climate during the Holocene. Science, v.278, p.1257-1266, 2001.

CAMARGO, O.A.; MONIZ, A. C.; JORGE, J.A.; VALADARES, J. M. A. S. Métodos de análise Química, Mineralógica e Física de solos do Instituto Agronômico de Campinas. Campinas: Instituto Agronômico, 2009, 77p.

CANCELLI, R. R. Evolução paleoambiental da planície costeira sul-catarinense (Lagoa do Sombrio) durante o Holoceno, com base em dados palinológicos. Tese (Doutorado em Ciências). Instituto de Geociências, Programa de Pósgraduação em Geociências, Universidade Federal do Rio Grande do Sul, Porto Alegre. 2012. 159f.

CASTILHO, A. M. A. Lagoas de Quiaios: Contribuição para o seu conhecimento geológico e hidrogeológico. Tese (Doutorado em Engenharia Geológica), Faculdade de Ciências e Tecnologia, Departamento de Ciências da Terra, Universidade de Coimbra, Coimbra, 2008. 474f.

CHAPMAN, M. R.; SHACKLETON, N. J. Evidence of 550-year and 1000-year cyclicities in North Atlantic circulation patterns during the Holocene. Holocene, v.10, p.287-291, 2000.

CORRÊA, I. C. S. Paleolinhas de costa na plataforma continental entre São Paulo e Santa Catarina. In: Simpósio Regional de
Geologia, 2., 1979, Rio Claro. Anais... Rio Claro: SBG. v. 1, p. 269-278.

CORRÊA, I. C. S. Les variations du niveau de la mer durant les derniers 17.500 ans BP: 1'exemple de La plate-forme continentale du Rio Grande do Sul, Brésil. Marine Geology, v. 130, p. 163-178, 1996.

DANTAS, M. E.; GOULART, D. R.; JACQUES, P. D.; ALMEIDA, I. S.; KREBS, A. S. J. Geomorfologia aplicada à gestão integrada de bacias de drenagem: bacia do rio Araranguá (SC), zona carbonífera sul-catarinense. In: Simpósio Brasileiro de Recursos Hídricos, 16., 2005, João Pessoa, PB., Anais... João Pessoa, PB: ABRH, 2005. 74p. CD Rom.

DIAS R. L., PEREZ FILHO, A. Geocronologia de terraços fluviais na bacia hidrográfica do rio Corumbataí-SP a partir de luminescência opticamente estimulada (LOE). Revista Brasileira de Geomorfologia, São Paulo, v.16, n.2, p.341-349, 2015a.

DIAS, R. L.; PEREZ FILHO, A (2015b). Uso de datações absolutas por Luminescência Opticamente Estimulada na interpretação da cobertura superficial holocênica em superfície de aplainamento na Depressão Periférica Paulista-Brasil. In: ZEZERE, J. L.; TRINDADE, J.; BERGONSE, B.; GARCIA, R. A. C.; OLIVEIRA, S. C.; PEREIRA, S. (Org.). VII Congresso Nacional de Geomorfologia. Geomorfologia 2015. 1ed. Lisboa: Associação Portuguesa de Geomorfólogos, v. 9, p.375-380, $2015 b$.

DUARTE, G. M. Depósitos cenozoicos costeiros e a morfologia do extremo sul de Santa Catarina. Tese (Doutorado em Geologia Sedimentar). Instituto de Geociências, Programa de Pós-graduação em Geologia Sedimentar, Universidade de São Paulo. 1995. 300f.

ENTING, I. G. On the use of smoothing splines to filter CO2 Data. J. Geophys. Res., v.92, p.977-984, 1987.

FLEMMING, B. W. A revised textural classification of gravel-free muddy sediments on the basis of ternary diagrams. Continental Shelf Research, v.20, n.10-11, p.1125-1137, 2000.

GAO, C.; ROBOCK, A.; AMMANN, C. Volcanic forcing of climate over the past 1500 years: an improved ice core-based index for climate models. J. Geophys, v.113, p.1-15, 2008.

GRAY,L.J.;BEER, J.; GELLER, M.;HAIGH,J.D.; LOCKWOOD, M.; MATTHES, K.; CUBASCH, U.; FLEITMANN, D.; HARRISON, G.; HOOD, L.; LUTERBACHER, L.; MEEHL, G. A.; SHINDELL, D.; VAN GEEL, B.; WHITE, W. Solar influences on climate. Rev. Geophys., v.48, 2010. 
GUPTA, A. K.; ANDERSON, D. M.; OVERPECK, J. T. Abrupt changes in the Asian southwest monsoon during the Holocene and their links to the North Atlantic Ocean. Nature, v.421, p.354-357, 2003.

HONG, Y. T.; HONG, B.; LIN, Q. H.; SHIBATA, Z.; HIROTA, M.; UCHIDA, M.; LENG, X. T.; JIANG, H. B.; XU, H.; WANG, H.; YI, L. Correlation between Indian Ocean summer monsoon and north Atlantic climate during the Holocene. Earth Planet. Sc. Lett., v.211, p.371-380, 2003.

HORN FILHO, N. O.; SCHMIDT, A. D.; BENEDET, C.; NEVES, J.; PIMENTA, L. H. F; PAQUETTE, M.; ALENCAR, R.; SILVA, W. B.; VILLELA, E.; GENOVEZ, R.; SANTOS, C.G. Estudo geológico dos depósitos clásticos quaternários superficiais da planície costeira de Santa Catarina, Brasil. Gravel, v.12, n.1, p. 41-107, 2014.

HUNTLEY, D. J.; GODFREY-SMITH, D. I.; HASKELL, E. H. Light-induced emission spectra from some quartz and feldspars. Nuclear Tracks and Radiation Measurements, v.18, p.127131, 1991.

HUNTLEY, D. J.; GODFREY-SMITH, D. I.; THEWALT, M. L. W. Optical dating of sediments. Nature, v.313, p.105-107, 1985.

HUNTLEY, D. J.; SHORT, M. A.; DUNPHY, K. Deep traps in quartz and their use for optical dating. Canadian Journal of Physics, v.74, p.81-91, 1996.

INTERGOVERNMENTAL PANEL ON CLIMATE CHANGE (IPCC). Climate Change 2007: The Physical Science Basis. Cambridge University Press, Cambridge and New York, 2007.

JENNINGS, A. E.; KNUDSEN, K. L.; HALS, M.; HANSEN, C. V.; ANDREWS, J. T. A mid-Holocene shift in Arctic sea-ice variability on the East Greenland Shelf. Holocene, v.12, p.49$58,2002$.

KOMAR, P. D. Beach processes and sedimentation. $1^{\text {a }}$ ed. New Jersey: Prentice-Hall, 1976, 429p.

KOWSMANN, R. O.; COSTA, M. P. A.; VICALVI, M. A.; COUTINHO, M. G. N.; GAMBOA, L. A. P. Modelo de sedimentação holocênica na plataforma continental sul brasileira. In: Projeto REMAC: Evolução sedimentar holocênica da plataforma continental e do talude do sul do Brasil. Rio de Janeiro: Petrobrás, CENPES, DINTEP, cap. 2, p. 7-26, 1977.

KREBS, A. S. J. Contribuição ao conhecimento dos recursos hídricos subterrâneos da bacia hidrográfica do Rio Araranguá-SC. Tese (Doutorado em Geografia). Centro de Filosofia e Ciências Humanas, Departamento de Geografia, Universidade Federal de Santa Catarina. 2004. 375f.
KRIVOVA, N. A.; SOLANKI, S. K. Models of solar irradiance variations: Current status. Astron. Astrophys, v.29, p.151-158, 2008 .

LAMBECK, K.; ESAT, T. M.; POTTER, E. K. Links between climate and sea levels for the past three million years. Nature, v.419, p.199-206, 2002.

LIMA, G. L. Estratigrafia e palinologia e depósitos turfosos e alúvio-coluviais quaternários no parque estadual da serra do tabuleiro e planalto de São Bento do Sul, Santa Catarina. Tese (Doutorado em Geografia), Centro de Filosofia e Ciências Humanas, Departamento de Geografia, Universidade Federal de Santa Catarina, Florianópolis. 2010. 251f.

MANN, M. E.; ZHANG, Z.; RUTHERFORD, S.; BRADLEY, R. S.; HUGHES, M. K.; SHINDELL, D.; AMMANN, C.; FALUVEGI, G.; NI, F. Global signatures and dynamical origins of the little ice age and medieval climate anomaly. Science, v. 326, p.1256-1260, 2009.

MARTIN, L.; SUGUIO, K.; FLEXOR, J. M.; DOMINGUEZ, J. M. L.; BITTENCOURT, A. C. S. P. Quaternary sea-level history and variations in dynamics along the Central Brazilian coast: consequences on coastal plain construction. Anais da Academia Brasileira de Ciências, v. 68, p. 303-354, 1996.

MATTHEWS, J. A.; BRIFFA, K. R. The 'Little ice age': Reevaluation of an evolving concept. Geogr. Ann. v.87, n.1, p.17-36, 2005.

MILANKOVITCH, M. Théorie mathématique dês phénomenès thermiques produits par la radiation solaire. $1^{\text {a }}$ ed. Paris, France: Gauthier-Villars, 1920, 339p.

MURRAY, A. S.; WINTLE, A. G. Factors controlling the shape of the OSL decay curve in quartz. Radiation Measurements, v.29, p.65-79, 1998.

MURRAY, A. S; WINTLE, A. G. Luminescence dating of quartz using an improved single-aliquot regenerative-dose protocol. Radiation Measurements, v.32, n.1, p.57-73, 2000.

OLIVEIRA, M. A. T.; LIMA, G. L. Classificação de sedimentos quaternários em cabeceiras de vale através da aplicação do diagrama de Flemming: município de Campo Alegre, norte de Santa Catarina. São Paulo, UNESP, Geociências, v. 23, n. 1-2, p. 67-78, 2004.

OLIVEIRA, M. A. T.; PESSENDA, L. C. R.; BEHLING, H.; LIMA, G. L.; FERREIRA, G. M. S. S. Registro de mudanças ambientais pleistocênicas e holocênicas em depósitos de cabeceira de vale: Campo Alegre, planalto norte catarinense (SC). Revista Brasileira de Geociências, v. 36, n.3, p.474-487, 2006. 
PEJRUP, M. The triangular diagram used for classification of estuarine sediments: a new approach. In: DE BOER, P. L.; VAN GELDER, A.; NIO, S. D. (Eds.), Tide-Influenced Sedimentary Environments and Facies. Reidel, Dordrecht, p.289-300, 1988.

PESSENDA, L. C. R; ARAVENA, R.; MELFI. A.J.; BOULET, $\mathrm{R}$. The use of carbon isotopes (C-13, C-14) in soil to evaluate vegetation changes during the Holocene in central Brazil. Radiocarbon, v.38, n.2, p.191-201, 1996.

PONTELLI, M. E. Pedomorfoestratigrafia de depósitos de leques aluviais: bacia do Rio Itoupava, sul do Estado de Santa Catarina. Tese (Doutorado em Geografia). Centro de Filosofia e Ciências Humanas, Programa de Pós-Graduação em Geografia, Universidade Federal de Santa Catarina. 2005. $220 f$.

PONTELLI, M. E.; PELLERIN, J. Estratigrafia relativa dos depósitos de leques aluviais nas bacias hidrográficas dos rios Rocinha e Amola-Faca: Timbé do Sul (SC). In: SIMPÓSIO NACIONAL DE GEOMORFOLOGIA, 2, Geosul, v.14, n.27, edição especial, p.457-461, 1998.

RAILSBACK, L. B.; GIBBARD, P. L.; HEAD, M. J.; VOARINTSOA, N. R. G.; TOUCANNE, S. An optimized scheme of lettered marine isotope substages for the last 1.0 million years, and the climatostratigraphic nature of isotope stages and substages. Quaternary Science Reviews, v.111, p.94-106, 2015a.

RAILSBACK, L. B.; BROOK, G. A.; ELLWOOD, B. B.; LIANG, F.; CHENG, H.; EDWARDS, R. L. A record of wet glacial stages and dry interglacial stages over the last $560 \mathrm{kyr}$ from a standing massive stalagmite in Carlsbad Cavern, New Mexico, USA. Palaeogeography, Palaeoclimatology, Palaeoecology, v.438, n.15, p.256-266, 2015b.

REINECK, H. E.; SIEFERT, W. Faktoren der Schlickbildung im Sahlenburger Watt und Neuwerker Watt. Die Küste, v.35, p.26-51, 1980.

SALlUN, A. E. M.; SUGUIO, K.; TATUMI, S. H.; YEE, M.; SANTOS, J.; BARRETO, A. M. F. Datação absoluta de depósitos quaternários brasileiros por luminescência. Revista Brasileira de Geociências, v.37, n.2, p.402-413, 2007.

SCHNEIDER, P. T. H. Análise paleopalinológica de sedimentos do quaternário sul-catarinense. Trabalho de Conclusão de Curso (Bacharelado em Ciências Biológicas). Instituto de Biociências, Universidade Federal do Rio Grande do Sul. 2012. 80f.

SHACKLETON, N. J. The last interglacial in the marine and terrestrial record. Proceedings of the Royal Society of London, v.174, p.135-154, 1969.
SHEVENELL, A. E.; INGALLS, A. E.; DOMACK, E. W. Orbital and atmospheric forcing of western Antarctic Peninsula climate in the Holocene: The TEX86 paleotemperature record of Palmer Deep. U.S. Geological Survey and The National Academies, 2007.

SOUZA, A. O.; PEREZ FILHO, A. (2015). Evidências neotectônicas e mudanças climáticas em terraços fluviais da bacia do ribeirão Araquá, São Paulo, BR. In: ASSOCIAÇÃO PORTUGUESA DE GEOMORFÓlOGOS (org.). Geomorfologia 2015. $1^{a}$ ed. Lisboa: Associação Portuguesa de Geomorfólogos, v.9, p. 123-129.

STEINHILBER, F.; BEER, J.; FRÖHLICH, C. Total solar irradiance during the Holocene. Geophys. Res. Lett., v.36, p.1-5, 2009.

STEVAUX, J. C. Climatic events during the Late Pleistocene and Holocene in the Upper Paraná River: Correlation with NE Argentina and South-Central Brazil. Quaternary International, v.72, n.1, p. 73-85, 2000.

STORANI, D. L. Cenário regional das oscilações climáticas quaternárias: baixos terraços fluviais no contexto da Depressão Periférica e do Planalto Ocidental Paulista. Tese (Doutorado em Geografia). Instituto de Geociências, Departamento de Geografia, Universidade Estadual de Campinas. 2015. 104f.

STORANI, D. L.; PEREZ FILHO, A. Novas informações sobre geocronologia em níveis de baixo terraço fluvial do rio Mogi Guaçu, SP, Brasil. Revista Brasileira de Geomorfologia, São Paulo, v.16, n.2, p.191-199, 2015.

STOTT, L.; TIMMERMANN, A.; THUNELL, R. Southern Hemisphere and deep-sea warming led deglacial atmospheric CO2 rise and topical warming. Science, v.318, p.436-438, 2007.

SUGUIO, K.; MARTIN, L. (1978). Quaternary marine formations of the states of São Paulo and southern Rio de Janeiro. In: International Symposium on coastal evolution in the Quaternary, 1., 1978, São Paulo. Special Publication $n^{\circ} 1$. São Paulo: Brazilian National Working Group for the IGCP- 61, n.1, p. 1-55 p.

SUGUiO, K.; MARTIN, L.; BITTENCOURT, A. C. S. P.; DOMINGUEZ, J. M. L.; FLEXOR, J. M.; AZEVEDO, A. E. G. Flutuações do nível relativo do mar durante o Quaternário superior ao longo do litoral brasileiro e suas implicações na sedimentação costeira. Revista Brasileira de Geociências, v. 15, p. 273-286, 1985.

SUGUIO. K. Tópicos de Geociências para o Desenvolvimento Sustentável: As Regiões Litorâneas, Geologia USP: Série 
Didática, v.2, n.1, p. 1-40, 2003.

THOMAS, M; THORP, M. B. Geomorphic response to rapid climatic and hydrologic change during the late Pleistocene and Early Holocene in the humid and sub-humid tropics. Quaternary Science Reviews, V. 14, p.193-207, 1995.

TOMAZELLI, L. J.; VILLWOCK, J. A. O Cenozóico no Rio Grande do Sul: Geologia da Planície Costeira. In: HOLZ, M.; DE ROS, L. F. (org.). Geologia do Rio Grande do Sul. Edição CIGO/UFRGS, Porto Alegre, p. 375-406, 2000.

TROUET, V.; ESPER, J.; GRAHAM, N. E.; BAKER, A.; SCOURSE, J. D.; FRANK, D. C. Persistent positive north Atlantic oscillation mode dominated the medieval climate anomaly. Science, v.324, p.78-80, 2009.

UNited StATES, SOIL SURVEY STAFF. Soil Survey manual. Washington, D.C: Department of Agriculture. Soil Conservation Service, 437p. (USDA. Agriculture. Handbook, 18) $2^{\mathrm{a}}$ ed. 1993.

VAN ANDEL, T. H.; LABOREL, J. Recent high sea-level stand near Recife, Brazil. Science, v. 145, p.580-581, 1964.

VIAU, A. E.; GAJEWSKI, K.; FINES, P.; ATKINSON, D. E.; SAWADA, M. C. Widespread evidence of $1500 \mathrm{yr}$ climate variability in North America during the past 14,000 yr. Geology, v.30, p.455-458, 2002.

VILLWOCK, J. A. Geology of the Coastal Province of Rio Grande do Sul, Southern Brazil. A Synthesis. Pesquisas, v.16, p.5-49, 1984.

VILLWOCK, J. A.; TOMAZELLI, L. J. Holocene Coastal Evolution in Rio Grande do Sul, Brazil. Quaternary of South America and Antartic Peninsula, v.11, p.283-296, 1998.

WANNER, H.; BEER, J.; BÜTIKOFER, J.; CROWLEY, T. J.; CUBASCH, U.; FLÜCKIGER, J.; GOOSSE, H.; GROSJEAN, M.; JOOS, F.; KAPLAN, J. O.; KÜTTEL, M.; MÜLLER, S.; PRENTICE, I. C.; SOLOMINA, O.; STOCKER, T. F.; TARASOV, P., WAGNER, M.; WIDMANN, M., Mid- to late Holocene climate change: an overview. Quaternary Science Reviews, v.27, p.1791-1828, 2008.

WANNER, H.; SOLOMINA, O.; GROSJEAN, M.; RITZ, S. P.; JETEL, M. Structure and origin of Holocene cold events. Quaternary Science Reviews, v.30, p.3109-3123, 2011.

WERNER, M.; WOLFF, E. W. Orbital and millennial Antarctic climate variability over the past 800,000 years. Science, v.317, p.793-796, 2007.

WILDNER, W.; CAMOZZATO, E.; TONiolo, J. A., BINOTTO, R. B.; IGLESIAS, C. M. F.; LAUX, J. H. Mapa geológico do Estado de Santa Catarina. Porto Alegre: CPRM, 2014. Escala 1:500.000. Programa geologia do Brasil. Subprograma de cartografia Geológica Regional, 2014.

WINTLE, A. G.; MURRAY, A. S. Quartz OSL: Effects of thermal treatment and their relevance to laboratory dating procedures. Radiation Measurements, v.32, p. 387-400, 2000. 